\title{
ESSAYS
}

\section{CREDENCE, CHARACTER, AND THE RULES OF EVIDENCE: SEEING THROUGH THE LIAR'S TALE}

\author{
H. RICHARD UVILLER $\dagger$ \\ $O$, what a goodly outside falsehood hath $!^{1}$
}

\section{INTRODUCTION}

The trial of any case in the adversary inode, but especially criminal cases, relies heavily on the skill of a jury to recognize honesty and dishonesty in the accounts of witnesses. Most facts are proved by testimony. Even in those cases where documentary or physical evidence or the defendant's confession is available to assist the factfinder, the human recital-viva voce-is often crucial to the establislunent of its authenticity or significance. Accordingly, we have developed elaborate forms and devices to assist our lay jurors in what is, under the most favorable circumstances, a highly problematic undertaking. Indeed, the adversary trial might be fairly described as a structured process for the determination of the credibility of strangers, inany of whom will, for one reason or another, try to deceive those who rely upon their word. Our faith in the adversary system-still a significant element in the determination of guilt ${ }^{2}$-depends in large measure on our confidence

$\dagger$ Arthur Levitt Professor of Law, Columbia University. The author expresses appreciation for comments on an earlier draft to Professors Ronald Allen, Kent Greenawalt, John Leubsdorf, and James Liebnian. And thanks for research assistance, especially in the psychological literature, to Kathrin Wanner. For support during summer work, I am grateful to the Walter E. Meyer Fund.

1. William Shakespeare, The Merchant of Venice act 1, sc. 3, line 101, in THE COMPLETE WORKS (Stanley Wells \& Gary Taylor gen. eds., 1988) (1600).

2. Settlement, the prevailing mode of disposing of criminal as well as civil cases, relies in significant part on the contemplation of an adversary forum. And the general uncertainty of when a cause in dispute will require resolution by trial imbues the adversary mode with major impact on the thinking of litigators. Then too, to the general pub- 
that, assisted by courtroom procedure, our jurors will usually return a verdict consistent with the historical fact. ${ }^{3}$

Understandably, few have tried to verify this critical assumption. As a practical matter, we have no better way to discover the historical truth underlying a case than the trial process itself. So the only post facto checks we have on jury verdicts are dubious anecdotal complaints from disappointed parties and occasional judicial expressions of agreement or disagreement based on hittle more than the jury had to go on. Whereas some commentators have placed great faith in the latter, ${ }^{4} \mathrm{I}$ find the evidence of accord insignificant and the evidence of dissent insolubly ambiguous. ${ }^{5}$ However, it may be possible to obtain an assessment of the rehability of the trial mode for the attribution of credence from the front end-from an examination of the devices available to a jury for its determination.

Before a description of how I propose to approach that undertaking, it might be fitting to ask whether there is any good reason to challenge the central tenet of the American systein of adjudication. It might be seriously argued that myth is the mortar of the justice system anyway, and that as long as the assumptions drive a mechanism that turns out a result generally accepted by the people, the system works. Greater-and needless-evil is done, the argument runs, by undermining basic props of a working systein than by living with hidden fiaws. The justice system, in short, is not like a bridge whose embedded faults may bring it crashing down; it is more like a political democracy wherein the fact that each voter is not equally well situated or equipped to cast an intelligent vote is better ignored than recognized.

I generally appreciate the wisdom of the cultural myth preservers. And I hesitate to offer the credo of the heedless social philosopher that pursuit of truth is always good, for the outcome

lic-as well as to the participants-the relatively few cases that proceed to verdict represent the system; their outcome, one by one, is vital to our continuing belief in justice through law.

3. A few years back, Professor Charles Nesson reminded us that public acceptance of verdicts as statements about historical reality was an important aspect of the rule of law. See Charles Nesson, The Evidence or the Event? On Judicial Proof and the Acceptability of Verdicts, 98 HARV. L. REv. 1357, 1366-68 (1985). But surely accuracy is a factor in acceptability.

4. See, e.g., Harry Kalven, JR. \& HaNs Zeisei, THE AMERICAN JURY (1966).

5. See infra Part I. 
of doubt is not cynicism and collapse but new and stronger structures. But I do believe that if the fair appraisal is unfavorable to our historic and trusted adversary process, alternatives may be available that will serve the same needs more effectively.

With due appreciation of the incompleteness of this research, of the tentative nature of my data, and of the contrary impression of most trial judges, I am led by my investigations to serious doubt concerning the ability of a trial jury to perform the central task assigned to them: to assess credibility. And, I must add, insofar as I can determme, the laws of evidence and the contribution of the trial courts in interpreting and applying the laws do little to enhance confidence.

My plan is, in Part I, to attempt a description of the task of a trial jury in evaluating the element of credence. I will enumerate and describe the several traditional and recognized methods for reaching a judgment, allowing myself an opinion concerning the reliability of each method. In Part II, I will focus on one of the central devices: character. The Federal Rules of Evidence are notably explicit in controlling the use of evidence of character on the issue of credibility, ${ }^{6}$ even boasting a recent amendment that bears some close scrutimy. In Part III, I will offer some crude data of how a substantial segment of the trial bench deal with evidence of character. The data will not speak well for either the clarity or consistency of a rule-driven system of trial. Trial judges report themselves in wide disarray concerning basic issues of interpretation. Finally, I will modestly propose, or more fairly put, will endorse the occasional proposals of others for, serious consideration of an alternative to the cherished adversary mode: an enriched mquisitorial ingredient in the criminal process.

6. The use of evidence of character is the only impeachment device expressly regulated by the Federal Rules of Evidence. 3 JACK B. WEINSTEIN \& MARGARET A. BERGER, WEINSTEIN's EVIDENCE $q$ 608[01] (1991). Although it alludes to impeachment by prior inconsistency, Rule 613 does not define the process but instructs only to whom and when the prior statement must be disclosed and how an opportunity to explain the inconsistency should be accorded.

My focus here on the Federal Rules of Evidence, admittedly convenient, does not altogether exclude state law since, the Federal Rules now have many state clones. For a collection of state jurisdictions adopting and modifying Rules 608 and 609 , see 3 id. III 608[09], 609[12]. 


\section{TRUTH AND THE AdJUdicative PRocess}

At the outset, it should be noted that witness credibility is burdened with two quite different problems. The first concerns a witness who, despite sincere efforts to report the facts fully and honestly, misperceives events; the second concerns a witness who-for whatever reason-consciously distorts recalled perceptions and events. In point of fact, the line between the two may not always be entirely distinct. Intentional misrepresentation may be motivated by the same sort of high emotional interest that sometimes causes an innocent misperception. Still, it is useful to regard as different characters the liar and the honestly mistaken witness.

The impediments to accuracy for those who try for it are generally thought to be three: inadequate acuity of perception, defects in recollection, and poor skills of recital. To reveal these flaws in credibility, the law of evidence relies principally on crossexamination and contradiction. By eliciting from the witness the things she did not notice or forgot, or by adducing extrinsic proof that the things were not as the witness perceived, recalled, or recited, an adverse party has long been assumed to be fully equipped to enlighten the factfinders as to the relevant skills of the witness.

Things are changing in this arena, however, and the journals and courtrooms are smoking with controversy. The work of psychologists, in and out of the courtroom, has suggested that ordinary common sense-the juror's needle and thread-is ill-suited to, and in some regards misleading in, the assessment of the accuracy of perception and recall. ${ }^{7}$ As interesting or disturbing as the human frailty of the perceptor/witness may be, however, I consider here only the difficulties of the job of the jurors as they perceive the testifying witness. ${ }^{8}$ Understanding that the faculties for the

7. See, e.g., Steven I. Friedland, On Common Sense and the Evaluation of Witness Credibility, 40 CASE W. RES. L. REv. 165, 178-88 (1989-1990). Most notably, evidence of this sort relates to accuracy of recognition of the face of a stranger. Of the several scholars and social scientists writing on the subject, the best known is probably Elizabeth $\mathrm{F}$. Loftus, the author of EYEWITNESS TESTIMONY (1979) and other works, and a frequent expert witness for the defense.

8. For discussions of the errors of the honest witness and the tendency of the adversary system to compound them, see D.S. Greer, Anything but the Truth? The Reliability of Testimony in Criminal Trials, 11 BRTT. J. CRIMINOLOGY 131 (1971), and Elaine D. Ingulli, Trial by Jury: Reflections on Witness Credibility, Expert Testimony, and Recan- 
accurate perception and rendition of the primary reality are closely related to the skills of the factfinder in perceiving the secondary, testimonial reality, I choose here to focus on the narrow but crucial matter of judging credibility and the assistance that the law of evidence purports to provide in the accomplishment of that task.

\section{A. Jurors as Lie-Detectors}

At the heart of our adversarial mode of adjudication lies the assumption that trial jurors-a fair mix of ordinary, relatively openminded folk - can from across the jury rail distinguish liars from truthtellers. ${ }^{9}$ The setting, unfortunately, is hardly the sort of scene in which ordinary folk are called upon to assess credibility in their normal lives. In a courtroom, witnesses are generally well rehearsed and carefully groomed for their appearance. Manyincluding the truthful-are nervous performing in the spotlight of a strange stage, subjected to friendly and overtly hostile interrogation in turn while being interrupted from time to time and instructed to answer in what must seem a peculiarly artificial manner. Ordinary, comfortable locutions appear out of place. Control of the narrative is taken away from the narrator. Nothing is conducive to spontaneity.

The jurors, meanwhile, are required to make their courtroom assessinents from an unaccustomed posture of passivity, asking no questions of their own, perhaps irritated at the long and seemingly pointless examination conducted by the lawyers, and forbidden to share their immediate reactions with one another.$^{10}$ Nevertheless, we take pains to provide the jurors with what we consider the essential ingredients of truth detection, along with some advice on how these ingredients should be employed. And we sustain our faith that these tools of credibility serve our jurors well in finding the facts.

tation, 20 VAL. U. L. REV. 145 (1986).

9. Juries are waived in some trials, both civil and criminal. We might expect that the sophistication of a judge sitting as factfinder would greatly improve the reliability of verdicts. However, from what little we know, the likelihood is that judges evaluate credibility much as jurors do. See infra note 111 and accompanying text.

10. I had occasion to discuss the agonies and errors in the deliberative process in connection with an analysis of erroneous verdicts of acquittal. See H. Richard Uviller, Acquitting the Guilty: Two Case Studies on Jury Misgivings and the Misunderstood Standard of Proof, 2 CRIM. L.F. 1 (1990). 


\section{B. Impeachment Generally}

All witnesses are presumed truthful and accurate at the start. Proof of veracity is generally not allowed except to rehabilitate those whose honesty or acuity has been impeached. The means available to lawyers for the exammation of a witness's credibilitywhich we may fairly assume are fully exploited in most cases-fall into six species. ${ }^{11}$ The first three may be called substantive in that they are content-oriented. These methods argue falsity from what is said by the witness in testimony. The next two may be termed motivational in that they are oriented to the personal reasons why the witness may distort the facts. A sixth I call behavioral. It derives cues entirely from the manner in which a witness presents a story. These three categories contain the complete kit of credibility scales and calipers furnished to trial jurors. The six processes they comprise may be described as follows.

\section{Substantive Impeachment.}

a. Contradiction. A lawyer may attempt to show that a witness is altering the truth by adducing proof from a different source that contradicts the witness's version. By general rule, evidence of this sort, being "extrinsic," must bear on a material aspect of the impeached witness's story. ${ }^{12}$ So the method may be viewed primarily as a ineans of proving facts in issue and only incidentally as an attack on the credibility of the witness contradicted.

Insofar as contradiction is considered a form of impeachment, it simply compounds the credence call. Jurors must now compare the credibility of the impeached witness with that of the impeaching witness. Unless the contradicting evidence is unimpeachable-or, at least, highly consistent with other reliable data-its introduction does little to solve the puzzle of the impeached witness's veracity. The game simply becomes a "swearing contest," requiring the jury to resolve the issue by resort to one of its other devices for the measurement of verity.

11. Different writers count them differently; McCormick, for example, counts five. Charles T. MCCORMICK, MCCORMICK ON EvidENCE $\$ 33$ (Edward w. Cleary et al. eds., 3d ed. 1984).

12. Id. \& 47 . 
b. Inconsistency. A lawyer may impeach a witness by showing that the witness on prior occasions gave an account significantly different from her present trial testimony. Proof of such prior inconsistency does not violate the rule against hearsay because it does not seek to prove the truth of the prior declaration, but only the fact that the witness is the sort of person who says different things at different times-and is hence a source unworthy of belief. ${ }^{13}$

Actually, inconsistency in a material particular may be one of the best indices of unreliability, and impeachment in this mode may be-and should be-very effective. One is rightly suspicious of the witness whose story has changed. But frequently, the impeached witness, entitled to an opportunity to explain, ${ }^{14}$ comes up with some pretty good reasons for the discrepancy: she was excited and reacted to imprecise data on the prior occasion; she had a false sense of conflicting obligation when she made the first statement; she was confused and accepted the version of a more certain colleague, and so on. Hearing these, the juror must evaluate the plausibility of the excuse and judge the veracity of the testimonial account accordingly.

What guides are available for this ancillary evaluation? No others than the usual. We trust to the "good sense" of the jurors in recognizing plausibility, the same sort of test the jurors will apply to the testimony as a whole. In other words, the device of prior inconsistency, rather than providing an independent basis for the attribution of credence, may supply merely an additional datum itself requiring measurement for truthfulness.

c. Incoherence. Normally, cross-examination challenges a rendition for its flaws of omission, embroidery, or implausibility. This is the ordinary mission of the cross-examiner. Books have been written about and dramas on our several screens have featured cross-examination; and practitioners sell their talents at the craft Wigmore praised as "beyond any doubt the greatest legal engine ever invented for the discovery of truth." 15 And in many

13. Id. § 34 .

14. See, e.g., FED. R. EVID. 613(b).

15. 5 JOHN H. Wigmore, EVIDENCE In TRIALS AT COMMON LAW \& 1367 (James H. Chadbourn rev. ed., 1974). The Supreme Court added its endorsement to this dubious tenet of the adversary mode as recently as 1992. See White v. Illinois, $112 \mathrm{~S}$. Ct. 736, 743 (1992) (quoting California v. Green, 399 U.S. 149, 158 (1970)). 
ways, cross-examination seems the best way of discerning conscious falsehood. The lie-especially uttered by the amateur liarshould fail the plausibility test in some respect. Life experience, one would think, has taught us all something of how the world works, and fiction will smell of its artificiality in some way, especially when pushed and stretched by cross-examination.

Surely all would agree that there have been some instances im which the press of interrogation has squeezed the truth from a disinclined witness, or at least revealed the unmistakable signs of falsehood. But there are also cases in which skillful cross-examination has made the honest witness hesitant, confused, or defiant, and has misled the factfinder to reject truthful evidence. And if the barristers are fair, they would probably agree with the judges that, in most encounters, the match is a draw-some hits, some misses, and the jury still unsure whether the lawyer has infiicted witness-abuse on an honest citizen or has shown up a cunning liar.

Aside from cross-examination, the element of coherence is probably the central cognitive mechanism for ascribing credence. The process by which a juror tests a story for plausibility involves some sort of cerebral inatching. ${ }^{16} \mathrm{~A}$ juror juxtaposes a set of recounted actions and events against her experience, imagination, and derived intelligence concerning the behavior and reactions of real and fictitious others: "Is this the sort of thing I might do in those circumstances?" "Would anyone I know have reacted that way?" "From what I've seen of cops on TV, would they have done it this way?" These are the sorts of guides to plausibility on which the juror must rely.

The trouble, of course, is that frequently the cultural context and customs of the actors in the events recounted by the witnesses are totally alien to the jurors seeking a plausibility match. Neither the jurors nor anyone they are likely to know have had any experiences comparable to those now described from the witness stand by an adolescent drug dealer or a professional underworld hoodlum. How a cocaine-crazed person who has just stabbed his girlfriend and her infant child would react when confronted by police is beyond the resources of imagination of most jurors. And with no referent in experience, with no capacity to understand behavior and events by projection, and with appropriate mistrust of fiction,

16. For a detailed study of jury decisionmaking, see REID HASTIE ET AL, INSIDE THE JURY (1983). 
the jury's quest for plausibility degenerates into a worthless assessment of possibilities. "It could have happened that way" gets the jury nowhere, simce it could have happened any number of ways; it is far from a judgment on the most likely way it actually happened.

Thus, the well-worn tools of "common sense and ordinary experience," which jurors are enjoined to use in deciding how far to beheve the witnesses, may be useless as jurors listen to witnesses and contemplate circumstances far from the paths of their own lives. Even where some correspondence may be found between the jurors' lives and the events they are called upon to imagine, plausibility is a highly uncertain standard. "Sure, that makes sense" or "Oh yes, I knew someone just like her who might have done just that sort of thing" are hardly reactions by which a complex patchwork of past events may be stitched together with confidence. While some of us characteristically rely on the "ring of truth" for all sorts of important decisions, others of us (lacking perfect pitch) mistrust that ring and are constantly reminded that unlikely things occur in life all the time.

Judgment by appeal to the sense of plausibility is at the heart of this or any conceivable system for the reconstruction of past events. But even historians know that plausibility-the inescapable standard-is culture-driven and hardly deserves the trust we are forced to repose in it. Moreover, the uncertainty of the plausibility standard may be aggravated in the adversary mode, in which those charged with the measurement of plausibility have limited access to contextual detail and irrelevant bits of information that flavor the account laid before them. The evident weakness of the plausibility index in the criminal trial must be accepted as a necessary factor contributing to uncertainty in the outcome. But it should not be ignored. The price of false confidence in the acuity of common sense and ordinary experience is groundless faith in the jury system and dullness in its improvement.

\section{Motivational Impeachment.}

a. Bias. By this common method, an adverse party attempts to suggest that a witness has some positive or negative connection to the parties or the cause such that the personal interests of the witness might motivate a conscious (or unconscious) effort to affect the result. Although impeachment-by-bias is not specifically recognized in the Federal Rules of Evidence, the Su- 
preme Court (nominal author of the Rules) has read this ancient ground for discredit into the Rules in their common law form. ${ }^{17}$

Traditionally, impeachment by proof of bias is distinct from other motivational impeachinent in that bias may always be proved by extrinsic evidence. ${ }^{18}$ It is not altogether clear why the suspected connection between a witness and a party or a supposed stake the witness has in the outcome cannot be fully explored by examination of the witness herself. The proportion of distraction to enlightenment should be constant whether the extrinsic evidence relates to mendacious character, prior inconsistency, or bias.

Stranger still is the rule that a witness impeached for bias may not be rehabilitated by evidence of a truthful disposition. The idea seems to be that there is no inconsistency between a specific sympathetic or hostile connection to the parties or to the action and a generally honest character. True, the most honest witness may happen to be related by marriage to the defendant's brother; or a person with the highest regard for the obligations of the oath may be hoping to have a sentence reduced on account of cooperation. In this respect, evidence of truthful character does not contradict evidence of bias. But the relevance of evidence of bias is in the line of inference from the witness's interest in the case to a slant in his testimony according with his interest. Temptation to fabricate is the implicit ingredient, and our general susceptibility allows the inference to flow. Character for strict adherence to

17. In a memorable case, United States v. Abel, 469 U.S. 45, 49-52 (1984), the Supreme Court noted that, while the scope of impeachment was governed by the Federal Rules of Evidence, the Rules contain no specific allowance of impeachment by showing bias. Acknowledging that they were "nominally" promulgators of the Rules, the Court evaded responsibility for the omission and joined the commentators who reject congressional intent to "scuttle" this time-honored method. Citing considerations of relevance and the comments of the Advisory Committee Reporter, the Court held that impeachment-bybias survives its omission in the Rules, and the prosecutor was allowed to call a witness to show that a defense witness and the defendant were members of a secret prison gang called "The Aryan Brotherhood," whose members were pledged to deny the gang's existence and to commit perjury, theft, and murder to help one another.

It is a bit odd that the Court in Abel found it necessary to restore bias to the armament of impeachment despite its oinission from the Federal Rules of Evidence. No means of impeachment other than character is expressly acknowledged in the Rules, yet no one has suggested that other traditional modes have been implicitly abolished by omission.

18. Bias, the saying goes, is never collateral. MCCoRMICK, supra note $11, \S 40$. Thus, if the witness denies the suspicious connection, the impeaching party is "not required to 'take the answer.'" Id. 
truth is the best antidote to such temptation, and one would think that evidence of the witness's attitude in this regard should always be admissible to block the hine of inference suggested by the impeaching evidence of bias.

As an instrument of impeachinent, evidence of bias (unrelieved by evidence of character) is a highly variable index of credibility. Few witnesses in criminal cases are entirely unbiased. Friends and relatives, business associates, the victim (contemplating a book or, perhaps, a lawsuit), a co-conspirator looking for leniency based on her performance as a witness, the rescuer whose ego has become involved with his heroism, law enforcement agents who may have citations or proinotions riding on the case-friendly or hostile, most witnesses have some interest in the outcome. Have these personal temptations to fabricate affected their renditions? Like the other guides to credibility, this factor's operation in credibility is inponderable.

Solne jurors might find that evidence of bias provides a substantial basis for disbelief, perhaps for the rejection, of a story they were uncomfortable with for other reasons. Other jurors, persuaded of the story, might just as readily discount the bias factor; after all, even the most interested witness can tell the truth, the whole truth, and nothing but the truth. As observers of the process, are we any better situated to judge which is the appropriate response in a given case? By itself, evidence of bias is hopelessly inconclusive. In conjunction with other indices of credence, it probably is an active ingredient only as a reinforcer, lending confidence-and ammunition for the jury room debate-to conclusions otherwise predicated.

b. Character. Despite the general rule against drawing an inference from character to conduct consistent therewith, ${ }^{19}$ proving the trait of truthfulness or deceitfulness is an allowable means for inducing a jury to believe or disbelieve testimony. ${ }^{20}$ The rule accords with common intelligence. Most of us heed a person's general respect for truth in deciding how to evaluate a particular datum offered for credit because we believe that behavior-including the act of rendering testimony-emanates froin personality.

19. See, e.g., FED. R. EVID. 404(a).

20. See infra notes $35-37$ and accompanying text. 
Evidence of character, however, as distinct from other modes of impeachment, is closely regulated by rule and judicial inclination. To some extent, these enacted and administered filters, finely appraising the proffered character evidence, serve the juror's instimctive curiosity. In other respects, the rules appear arbitrarily to frustrate the factfinder's need for helpful guides to credit. And to a large extent, the rules appear to be misunderstood, variously applied, or disregarded by the judges charged with their application. These matters are more fully explored in the pages that follow. ${ }^{21}$

\section{Behavioral Impeachment.}

a. Demeanor. This method attempts to read veracity or mendacity in the facial, vocal, and postural displays that accompany the witness's rendition from the stand. Sensitive, as usual, to commonplace assumptions, the law of evidence adopts the general practice of allowing credibility calls to rest on imchoate behavioral cues. Indeed, we go to considerable lengths to provide our empanelled jury with exposure to the voice tones, gestures, and expressions that accompany factual renditions. Not only does the rule against hearsay express a preference for live testimony rendered before the watching jurors, but the Constitution's Confrontation Clause enshrines demeanor evidence among the basic protections of the defendant in a criminal case. ${ }^{22}$

In fact, considerable data strongly suggest that the common faith in the telltale signs of prevarication is baseless. Professor Wellborn, concluding a detailed examination of the work of social psychologists studying the reliability of various behavioral cues, puts it this way:

Taken as a whole, the experimental evidence indicates that ordinary observers do not benefit from the opportunity to observe nonverbal behavior in judging whether soneone is lying. There is no evidence that facial behavior is of any benefit; sonie evidence suggests that observation of facial behavior diminishes the accuracy of lie detection. Nor do paralinguistic cues [i.e., voice quality and inflection] appear to be of value; subjects who

21. See infra Section $\mathrm{C}$.

22. See, e.g., Coy v. Iowa, 487 U.S. 1012, 1019-20 (1988); Ohio v. Roberts, 448 U.S. 56, 63-64 (1980); Davis v. Alaska, 415 U.S. 308, 316-17 (1974); Smith v. Illinois, 390 U.S. 129, 130 (1968). 
receive transcript[s] consistently perform as well as or better than subjects who receive recordings of the respondent's [witness's] voice. With respect to body cues, there is no persuasive evidence to support the hypothesis that lying is accompamied by distinctive body behavior that others can discern. ${ }^{23}$

Regrettably, flaws in the experimental models abound; even the best of thein contain at least one foolish component that might cast doubt on the significance of the conclusions. ${ }^{24}$ But overall, repeated experiments have reached the same conclusions, and we can hardly afford to ignore the cumulative conclusion, painful as it inay be to soine cherished assumptions of the process. ${ }^{25}$

Many people (judges among them) devoutly believe-and the law encourages the belief - that inendacity is betrayed in involuntary, observable, signs of stress recognizable by anyone who has hived in contact with fellow humans through the ordinary experi-

23. Olin G. Wellborn, III, Demeanor, 76 CORNELL L. REv. 1075, 1088 (1991). Wellborn goes on to report that the major determinant of juror credulity, experimenters have found, is witness confidence, a factor that, unfortunately, correlates weakly with veracity and accuracy. Id. at 1089. Likewise, another commentator reports, "mounting empirical data from psychological studies suggest that lay persons such as jurors inadequately evaluate the testimony of others." Friedland, supra note 7 , at 167.

24. Responding to widespread comment that the artificial, greatly simplified, lab models bore little resemblance to the courtroom where diligent and motivated juries debated consequential issues, a teain of soeial scientists in 1989 replayed an oft-replicated experiment of ten years before in which they had found no ability of subject jurors to distinguish correct froin incorrect identifications of the perpetrator of a staged crime. As reported by Wellborn, supra note 23 , at 1090 , crimes were again staged before witnesses, but this time "trials" were held soine weeks later, in real courtrooms, and-most importantly-with lawyers acting as examining and arguing counsel. These advocates were criminal lawyers and senior law students with some courtrooun experience. Sixteen trials were held, evenly divided between correct and erroneous identifications. Each witness underwent direct, cross-, and redirect examination (without time limit) followed by "closing statements" froin counsel. One liundred seventy-eight subjects in various "juries" viewed the videotapes. Sixty-eight percent of the jurors voted guilty on a correct identification; seventy percent voted guilty on a false identification. Moreover, the level of the trial attorney's experience had no effect on the outcome, though jurors correctly recognized the novices and rated their performances as inferior.

Of course, this study will not completely still lawyers' criticism of the social science methodology. It is typical of the infuriating flaw frequently encountered in a social scientist's experimental model that the issue chosen for this complex and otherwise meticulous study was an issue of identification-probably the least susceptible to credibility testing by even the most resourceful lawyers. Nor does the model faithfully reproduce the courtroom context of an actual trial with all its complexity and richness of detail.

25. Perhaps the most disturbing data are those demonstrating that certainty does not correlate with accuracy; an eyewitness's certainty is the single most determinative feature in the credence equation. Id. at 1089. 
ences of life. All the evidence available-and it is a considerable quantity-is to the contrary. Much as we would like to affirm the utility of the hearsay principle and the Confrontation Clause, much as we (or some of us) feel in our guts that we know a liar when we see one, it would be foolish for the critical observer to repose much confidence in the revelations of live testimony.

\section{Character as a Source of Impeachment}

Of the several methods for the recognition of truth, one of the most impressive and most troublesone is the one to which I now turn: character. In the realins of ordinary life, we accord great weiglit to our appraisal of cliaracter in judging behavior. To conclude that a person did or did not do a critical act, we want to know what kind of a person our subject is: Is that the sort of conduct one would expect froin a person of that character? Specifically, on the issue of credence, it is extreinely helpful to know whether the character of the witness reveals a respect for truth and the obligations of fair and accurate recital.

In the law of evidence-code and common law-the character trait of veracity or inendacity is, in a sense, anomalous. Despite (or naybe because of) its strong inferential link, evidence of a personality trait consistent with the primary conduct at issue will generally be excluded froin the factfinder's consideration. ${ }^{26}$ Yet,

26. In an oft-quoted opinion, Justice Jackson wrote: "The inquiry is not rejected because character is irrelevant; on the contrary, it is said to weigh too unuch with the jury and to so overpersuade them as to prejudge one with a bad general record and deny him a fair opportunity to defend against a particular charge." Michelson v. United States, 335 U.S. 469, 475-76 (1948) (footnote omitted). I too have elsewhere expressed some thoughts on the rules regarding character as evidence of behavior. $H$. Richard Uviller, Evidence of Character to Prove Conduct: Illusion, Illogic, and Injusticc in the Courtroom, 130 U. PA. L. REV. 845 (1982) (advocating a revision of the Federal Rules that would admit character evidence to prove conduct consistent with it when such evidence is relevant and inore probative than prejudicial).

The text of the rule regulating evidence of character on the primary issue reads as follows:

Rule 404. Character Evidence Not Admissible to Prove Conduct; Exceptions; Other Crines

(a) Character evidence generally. Evidence of a person's character or a trait of character is not admissible for the purpose of proving action in conformity therewith on a particular occasion, except:

(1) Character of accused. Evidence of a pertinent trait of character offered by an accused, or by the prosecution to rebut the same;

(2) Character of victim. Evidence of a pertinent trait of character of the victim of the crime offered by an accused, or by the prosecution to rebut the 
evidence of the trait of truthfulness (or dishonesty) will generally be admitted to prove the secondary conduct of a witness in testifying truthfully (or untruthfully) from the witness stand. ${ }^{27}$ For instance, the character trait of dishonesty (or a prior conviction for fraud) will not be received as evidence that the defendant embezzled funds as charged in the indictment, but if the defendant should testify that he did not steal from his employer, the same evidence will be adinitted to prove he is lying on the stand. The framers of the Federal Rules of Evidence acknowledge-and uncritically perpetuate-the curious discontinuity in the theory of the coinmon law (if the common law can be said to have a "theory") relating to evidence of character. ${ }^{28}$

In allowing character evidence on the issue of credence, the law postulates several factual axioms:

same, or evidence of a character trait of peacefulness of the victim offered by the prosecution in a homicide case to rebut evidence that the victim was the first aggressor,

(3) Character of witness. Evidence of the character of a witness, as provided in rules 607,608 , and 609 .

(b) Other crines, wrongs, or acts. Evidence of other crimes, wrongs, or acts is not admissible to prove the character of a person in order to show action in conformity therewith. It nay, however, be admissible for other purposes, such as proof of motive, opportunity, intent, preparation, plan, knowledge, identity, or absence of mistake or accident.

Whereas the first subdivision of the rule, reflecting the cominon law, firmly withdraws character as a basis for an inference to conduct in the ordinary case, the second subdivision is read by some as substantially undercutting that rule. See, e.g., Richard B. Kuhns, The Propensity to Misunderstand the Character of Specific Acts Evidence, 66 IowA L. REV. 777, 779-96, 798-99 (1981). As "exceptions," the permitted purposes for proof of other misdeeds do cut a wide hole in the prohibition. However, an equally tenable construction of Rule 404(b) would take the enumerated allowances as proof for purposes other than the proof of character. In this view, all are situation-specific, tending to show the conduct in question by particular predicates such as inotive, opportunity, knowledge, and the rest, rather than by showing traits of general character from which the conduct might be inferred by predisposition. For a proposed procedural solution to the confusion regarding proof by extrinsic evidence of prior crimes, see Abraham P. Ordover, Balancing the Presumptions of Guilt and Innocence: Rules 404(b), 608(b) and 609(a), 38 EMORY L.J. 135 (1989).

27. The original Advisory Committee Note to Rule 608 is quite explicit on the allowance of character to prove propensity to falsehood. It states:

In Rule 404(a) the general position is taken that character evidence is not admissible for the purpose of proving that the person acted in conformity therewith, subject, however, to several exceptions, one of which is character evidence of a witness as bearing on his credibility. The present rule develops that exception.

FED. R. EvID. 608 advisory committee note.

28. The Advisory Committee Note to Rule 608(a) states that the Rule "develops [the] exception" to the general premise expressed in Rule 404(a). See supra note 27. 
1. Dishonest People Are More Likely to Lie in Any Given Situation than Honest People. Lack of respect for truth is a pervasive trait that affects testimonial veracity in all situations, regardless of other interests. Thus, for example, a bystander who once falsified an unrelated insurance clain is more likely to lie about whether the getaway car contained two blacks or two whites than is a witness of unbleinished career. And a defendant with no criminal record is more likely to tell the truth on the stand about his commission of the crime (though he had coinmitted it) than is a defendant with a record (though he is as innocent as the judge). Moreover, unlike the personality traits that may dispose a person to coinmit the conduct charged in the indictment, the predisposition to render a truthful or untruthful account from the stand is generally of sufficient reliability and discernibility to be entrusted to the evaluation of the jury.

2. The Character Trait of Veracity/Mendacity Is Detectable by Casual Observers in the Community, and the Community Consensus Is Accurately Transmitted Among Acquaintances. Those who reside or work in the same location as the subject are likely to learn of her reputation ainong neighbors and associates with regard to the specific attribute of "truth and veracity" (as it is usually termed). Commonly a subject of discussion among these casual acquaintances, reputation is a trustworthy distillation of a broad behavioral history in various circuinstances and hence a fair reflection of character. More recently, this preeminent index of character has accommodated discernment by personal experience. ${ }^{29}$ Thus, by a series of interactions, a person may form a general opinion of another's characteristic mode of dealing with the events of his life. And from the opinion of a casual acquaintance, as well as from the ruinor and report that qualifies as evidence of reputation, the trait of scrupulous regard for truth-or its absence-may be reliably inferred.

29. As a reflection of the usual practice of calling character witnesses who had dealings with the witness on which an opinion could be formed rather than reporters of cominunity gossip, the framers originally intended to replace reputation with personal opinion. As promulgated, however, the Federal Rules allow evidence in either form. FED. $R$. EviD. 608(a); see id. advisory committee note. 
3. Ordinary People, Properly Instructed as Jurors, Will Appreciate the Distinction Between an Inference from Dishonest Character to Untruthful Testimony and an Inference from Dishonest Character to Criminal Conduct. Further, their understanding will allow them to use such character evidence strictly for the evaluation of testimonial veracity without allowing it to color their judgment regarding the critical behavior at issue in the trial. For example, evidence that a testifying witness was known as a liar and a cheat will not influence the jury to conclude that the witness was part of a conspiracy to defraud investors, but will be narrowly applied to discredit the witness's testimony as to the point that he had no dishonest intentions.

It is not difficult to expose the weakness in these axioms and postulates. Thus stated in all their naked naivete, they reflect a view of human nature more suitable to the nursery than the courtroom. It is remarkable that a set of assumptions so far from the lessons of experience could support a fully developed and widely observed structure of litigation law. We all know that the inclination toward mendacity is a complex and subtle process. With the possible exception of a few sick minds, people generally tell mostly the truth to most people most of the time, and make more or less critical adjustments to a number of others some of the time, depending on the subject, the circuinstances, and the stakes. Neither truthtelling nor lying can be called a pervasive trait like a quick temper or a pessimistic outlook. Moreover, in my circles at least, friends and co-workers rarely discuss one another's characteristic respect for verity with each other. The idea is little short of ludicrous that I could report a reliable consensus on the subject, emerging from ordinary conversation, such that a rational prediction might be made concerning the truthfulness or falsity of some sworn declaration.

Those who hold to a rational predicate for modern law inust find their minds casting about for alternatives; the ones here cannot be the true underlying premises of the law of character and credence. They are certainly the ostensible premises; but perhaps there is some covert predicate, something a bit more realistic. The best alternative $I$ have been able to discover is hardly a model of 
rational precision. ${ }^{30}$ It grows from the need to put a more human face on the two-dimensional witness performing a well-rehearsed part in a professionally crafted persona in the witness box. It is, in effect, a rule founded on rebellion among the pragmatic judiciary against the controlled presentation of human recollection called for by courtroom protocol. An actor, detached from his personal history, retains no individuality by which to judge credibility. My surmise is that the artificiality of testimony constitutes such a dense barrier to recognition of the individual human traits on which we depend in life at large that some tunnel must be bored through it. However crude, the history of a witness living among his peers im the real world, the traces of character discernible in repute or personal opinion, afford some glimpse of the human being lurking behind the polished and wary figure in the witness box.

\section{CRedibility and the Federal Rules of Evidence}

It is often noted that the rulings that filter testimonial data for the jury are largely "discretionary." 31 By this sometimes uncertain designation is meant a considerable area of license in which the trial judge commits no error whatever the ruling. ${ }^{32}$ From the frequent appearance of the word "discretion" in appellate decisions, however, it would be wrong to conclude (as many trial judges apparently do) that the "law of evidence" is a misnomer. The decisions of judges regarding the limits of impeachment-as regarding many other issues-are circumscribed by com-

30. It does, however, seem rather more rational than the early Holmes rationale often quoted to support the rule of impeachment:

[W] hen it is proved that a witness has been convicted of a crime, the only groimd for disbelieving him which such proof affords is the general readiness to do evil which the conviction may be supposed to show. It is from that general disposition alone that the jury is asked to infer a readiness to he in the particular case, and thence that he has lied in fact. The evidence has no tendency to prove that he was mistaken, but only that he has perjured himself, and it reaches that conclusion solely through the general proposition that he is of bad character and unworthy of credit.

Gertz v. Fitchburg R.R., 137 Mass. 77, 78 (1884).

31. See, e.g., 1 WEINSTEIN \& BERGER, supra note 6, 9 401[01]; JoHN H. WIGMORE, Evidence IN TRIALS AT COMMON LAW $\S 16$ (Peter Tillers rev. ed., 1983).

32. In a short essay, Professor Jon Waltz undertook to examine the element of discretion, expressed and unexpressed, in the federal evidence code. Noting that discretion comes in different degrees (which he terms "guided" and "unguided"), he concluded that "the Rules are not laced with unprecedented grants of unbridled judicial discretion." Jon R. Waltz, Judicial Discretion in the Admission of Evidence Under the Federal Rules of Evidence, 79 NW. U. L. REV. 1097, 1118 (1984-1985). 
mon law or statutory rules. Even as they exercise their discretionary prerogatives, they do so within the framework of a rule identifying critical factors-for example, in deciding that a particular prior crime did or did not involve dishonesty, they do so within the framework of a rule identifying dishonesty as a critical factor. There is inore, then, to ruling on questions of evidence than a good "feel," a sense of fairness, and the confidence to say "objection sustained" or "objection overruled" with suitable authority.

Subjected to extensive exegesis and hermeneutic, modified, and encoded, the rules of evidence appear to be with us for the duration of the lay jury systein of factfinding. Today, they assume their most authoritative guise in the Federal Rules of Evidence. Drafted by a coinmittee appointed in 1965 by Chief Justice Earl Warren, the Rules were circulated in 1971 and prescribed by the Court in 1972 to take effect the following year. Congress studied, revised, and enacted the Rules as law effective July $1,1975^{33}$ The impulse was felt in states around the Union. Many states enacted virtual clones of the Federal Rules; others modified thein to a greater or lesser extent to reflect local common law. Although a number of states still languish codeless, many have drafts in the works-and soon (it is fair to predict), the evidentiary codification of the United States will be virtually complete. ${ }^{34}$

Rules 608 and 609 of the Federal Rules of Evidence represent our current effort to regulate the jury's access to information about the character of a witness as might enlighten the issue of credibility. In accord with the style of this modern codification, these rules are short; upon first reading, they seen to have a beguiling aspect of clarity and simplicity. Upon closer examination, several perplexing issues are found lurking beneath these rules' placid surface.

Specifically, three basic questions deserve analysis. First, are the rules regarding impeachinent to be applied evenly to prosecution and defense witnesses? Second, to what extent are the facts and circuunstances surrounding a prior conviction admissible to mitigate or aggravate the impact of that conviction? And third, are there any convictions that do not entail "dishonesty" that are

33. 88 Stat. 1926 (codified as FED. R. EVID., 28 U.S.C. 733-804 (1988)).

34. 5 WEINSTEIN \& BERGER, supra note 6 , at T-1 to T-164. 
nevertheless relevant to credibility-and if so, how are they to be recognized?

\section{A. Equal Opportunity to Impeach the Defendant, the Victim, and Other Witnesses on Both Sides}

Prior to December 1, 1990, neither Rule 608 nor Rule 609 made any explicit distinction between prosecution witnesses and defense witnesses (including the defendant himself). Rule 608 was, and continues to be, a simple provision dealing with the admissibility of evidence of character on the issue of credibility. The Rule is divided into two sections according to the form of the evidence offered on the issue of character. Rule 608(a) deals with evidence in the traditional form of reputation, augmented by the modern parallel, personal opinion. ${ }^{35}$ Under this section, evidence adduced to attack or support credibility is allowed, provided it specifically relates to the trait of veracity/mendacity, and provided further, evidence of truthfulness may be offered to support testimony only after the character of the witness has been attacked by opinion or reputation evidence of mendacity or by cross-examination that clearly implicates character. ${ }^{36}$ Rule $608(\mathrm{~b})$ treats evidence of truthful or untruthful character as it might be inferred from significant behavior. This section of the Rule provides that "specific instances of conduct" may not be adduced from sources "extrinsic" to the witness, but, insofar as relevant to the trait at issue, may be "imquired imto" on cross-examination "in the discretion of the court."

Rule 609 deals with a special case of impeachment by prior misconduct: evidence of prior criminal conviction. ${ }^{37}$ It was, we are

35. As previously noted, the original 1969 draft of the Federal Rules of Evidence reversed the rule at common law, allowing the evidence in the form of an opinion, but excluding evidence of reputation. See supra note 29.

36. The Rule says only "or otherwise," but most agree the reference is to raising the subject by cross-examination. Not all cross-examination, however, invites refutation by evidence of honest disposition. McCormick uses the adjective "slashing" to describe the sort of attack by cross-examination that invites evidence of good character. MCCORMICK, supra note $11, \S 49$, at 117 . But rather than intensity, the key factor is the implication of bad character in the substance of the cross-examination.

37. Impeachment by prior conviction found its way into modern law down the lanes of history rather than by inspired construction. Until late in the last century, conviction for an "infamous" (i.e., deceitful) felony rendered the felon incompetent to testify. Impeachinent is the residue of the rule of disqualification. It is widely deplored. Ed Gainor, Character Evidence by Any Other Name... : A Proposal to Limit Impeachment by 
informed, more thoroughly debated by Congress than any other rule in the federal evidence code ${ }^{38}$ and it is complex and problematic. Four of Rule 609's five sections-dealing with the effects of staleness, pardon or annulment, the pendency of an appeal, and the special case of prior adjudications of juveniles-do not concern us here. We focus on the first and principal section, stating the general rule. ${ }^{39}$

Until its recent amendment in 1990, Rule 609(a) appeared to take no note of the distinction between criminal defendants and other witnesses. It simply provided that evidence of a generic witness's prior criminal conviction, elicited on cross-examination or adduced from a public record, was admissible if the crine either (1) "involved dishonesty or false stateinent" (a soinewhat inexact category ${ }^{40}$ ) or (2) was a felony in the jurisdiction of commission, and its probative value outweighed prejudice to the defendant. ${ }^{41}$ This last prepositional phrase, however, effectively limited the operation of the rule to the exclusion of prior felony convictions

Prior Conviction Under Rule 609, 58 GEO. WASH. L. REv. 762, 770-71 (1990).

For recent additions to the oft-told history and development of Rule 609, see Edward H. Koster, Note, Witness Impeachment in Transition: Rule 609(a) in Green v. Bock Laundry Machine Co. and in the Subsequent Proposed Amendment, 21 U. TOL. L. REV. 957, 958-63 (1990), and Gamor, supra (suggesting a revision of Rule 609(a) that would strictly limit impeacliment of a defendant by evidence of prior conviction of crimes that involve false statement, deceit, or fraud subject to the probative value-prejudicial effect balancing test).

38. Stephen A. Saltzburg \& Michael M. Martin, Federal Rules of EviDENCE MANUAL 634 (5th ed. 1990).

39. The first section, effective as of December 1, 1990, provides:

(a) General rule. For the purpose of attacking the credibihity of a witness,

(1) evidence that a witness other than an accused has been convicted of a crime shall be admitted, subject to Rule 403 , if the crime was punishable by death or miprisonment im excess of one year under the law under which the witness was convicted, and evidence that an accused has been convicted of such a crime shall be admitted if the court determines that the probative value of admitting this evidence outweighs its prejudicial effect to the accused; and

(2) evidence that any witness has been convicted of a crime shall be admitted if it involved dishonesty or false statement, regardless of the punishment.

FED. R. EVID. 609(a).

40. See infra notes 71-77 and accoinpanying text.

41. Gainor states the old Rule 609(a) when he writes, "[P]rior felony convictions are always admissible for purposes of impeaching a prosecution witness." He notes, further, "Rule 403 never apphies to impeacliment by prior conviction," so the prosecutor could not appeal to the judge to exclude a prosecution witness's prior record even in a case of minimal probative value and overwhelming prejudice. Gainor, supra note 37,785 n.143 (citations omitted). 
of a testifying defendant, ${ }^{42}$ since admission of a prosecution witness's record would occasion no prejudice "to the defendant." ${ }^{33}$ That covert differentiation may-or may not-have been removed by the amendinent.

A solid argument might be made that the entire purpose of the amendment to Rule 609(a) was to clarify its application to civil cases, ${ }^{44}$ leaving the former distinction between impeachment of prosecution and defense witnesses-for better or worse-completely intact. The dozing drafters of the old version, with their careless phrase: "prejudicial effect to the defendant," seemed sinply to have overlooked civil trials. In a civil case, why should the impeachment of plaintiff's witnesses not be constrained by considerations of "prejudice to the plaintiff"? Thus, the primary purpose of the amendment may well have been to address the apparent inequity in the application of the rule to civil cases, ${ }^{45}$ a seemingly

42. The application of the phrase in the impeachment of defense witnesses other than the defendant is uncertain. While adducing their records seems unlikely to prejudice the defendant in the particular way of allowing an inference to the commission of the charged offense, some witnesses may be associated with the defendant in a manner that might suggest to the jury that if they were criminals, the defendant might be one too. In United States v. Blankenship, 870 F.2d 326, 329 (6th Cir. 1988), cert. denied, 489 U.S. 1068 (1989), the appellate court affirmed the trial court's decision under Rule 609(a) to permit the impeachment of a defense witness by a sodomy conviction. Prejudice to the defendant was less, the court noted, where the character of his witness rather than his own is under attack. Id. How the trial judge could have found any probative value in such a conviction to outweigh even minimal prejudice is unclear.

43. See H.R. CONF. REP. No. 1597, 93d Cong., 2d Sess. 9-10 (1974), reprinted in 1974 U.S.C.C.A.N. 7098, 7103; Campbell v. Greer, 831 F.2d 700, 704 (7th Cir. 1987) (non-defendant witnesses" "prior convictions are admissible for purposes of impeachment without any balancing test"). Prosecution witnesses, of course, could be cross-examined about misdemeanor convictions provided they involved dishonesty or false statement. In United States v. Nichols, 808 F.2d 660, 664 (8th Cir.), cert. denied, 481 U.S. 1038 (1987), for example, the court upheld a trial ruling precluding defense cross-examination of the government's FBI agent for intoxicated driving, a conviction that did not entail imprisonment for nore than one year, on the ground that the crime did not involve dishonesty.

The operation of the one-sided inquiry was not iron-bound, however. In United States v. Sellers, 906 F.2d 597, 602 (11th Cir. 1990), for instance, the court, while not expounding on the point, considered prejudice to the prosecution from impeachment by the defense of a government witness on account of prior drug use. Then, too, in some courtrooms, the measurement of prejudice to the defendant from impeachment by his convictions was affected by "prejudice" suffered by the prosecution from the same sort of impeachment. See Judicial Survey I, infra Appendix A, Question 10.

44. See, e.g., Koster, supra note 37.

45. Amendments to Federal Rules of Evidence Rule 609, 129 F.R.D. 347, 353 (1990) [hereinafter Cominittee Note]. 
unintentional and nonsensical flaw that had been noted by the Supreme Court the year before. ${ }^{46}$

According to the Advisory Committee Note, the amendment actually had two goals, and, seemingly, two only. The first was to make minor adjustments to allow the common practice of eliciting prior convictions on direct examination and to allow extrinsic evidence from sources other than the "public record," if necessary and if consistent with Rule $403 .^{47}$ The other-and major-purpose was to "resolve[] an ambiguity" concerning "impeachment of witnesses other than the criminal defendant." 48 While this language is not specifically directed to witnesses in civil cases and would comfortably accominodate prosecution witnesses in criminal cases, it is immediately followed by a citation to Green v. Bock Laundry Machine $\mathrm{Co}^{4}{ }^{49}$ a case inviting the amendinent to achieve parity between witnesses in civil cases. The Advisory Coinmittee Note goes on to state: "The amendment does not disturb the special balancing test for the criminal defendant who chooses to testify." 50 Thus, Congress may have intended only to broaden Rule 609(a) such that witnesses for both civil parties might be equally impeachable by prior convictions not unduly prejudicial to the adverse party. The Advisory Committee's delphic comment, however, says nothing about the special balancing of prejudice to the prosecution.

But whether intended or not, whether primary or secondary effect, the amendinent of Rule 609(a) has had a dramatic impact on the impeachment of prosecution witnesses in criminal cases. As now written, the new first subdivision of Rule 609(a) appears to be divided between impeachment of a defendant in a criminal prosecution and impeachment of witnesses generally (including criminal defendants). As to the latter, Rule 609(a)(2) provides simply that evidence that the testifying defendant or any other witness was convicted of any crime of any grade "shall be admitted" if the crime "involved dishonesty or false statement."

46. See Green v. Bock Laundry Mach. Co., 490 U.S. 504, 510 (1989).

47. Committee Note, supra note 45 , at 353 .

48. Id.

49. 490 U.S. 504 (1989).

50. Committee Note, supra note 45 , at 353 .

51. At least six circuits have held that the court has no discretion, under Rule 403 or otherwise, to exclude convictions in this category. 3 WEINSTEIN \& BERGER, supra note 6, I 609[4], at 609-43 to -45; see also Gainor, supra note 37, at 764-66 (discussing 
Rule 609(a)(1) is somewhat more complex. In form, it is internally divided into two parts: one expressly addressed to "an accused," the other to "a witness other than an accused." In operation, however, the nature of the distinction is elusive. The Rule provides that evidence that an accused testifying in his own behalf in a criminal prosecution was convicted of a crime unay be elicited (presumably either by examination of the defendant himself or by any extrimsic evidence) if (1) the prior crime was a felony under the law of the jurisdiction of commission, and (2) the probative value (on the issue of testimonial veracity) of admitting the evidence outweighs its prejudicial effect to the accused. ${ }^{52}$ For a witness other than an accused, evidence of a prior felony conviction may be adduced (in the same manner) "subject to Rule 403." Rule 403 provides, principally, that evidence is admissible if its probative value outweighs its potential for prejudice. Thus, the distimction that the new Rule 609(a) intends to draw is not immediately apparent. Taken together, Rule 609(a)'s two subdivisions appear to say that a witness for either side may be inpeached by evidence of prior conviction, provided that the probative value of the fact of conviction on the issue of credibility outweighs any dainaging side effects to the party calling the witness.

Technicians unight point to certain verbal distinctions between Rule 403 and the probity-prejudice language of Rule $609.5^{53}$ For

cases, legislative history, and commentary on the imperative language in $609(\mathrm{a})(2))$.

52. To many, this will be recognized as a rebirth of the so-called Luck rule, announced in Luck v. United States, 348 F.2d 763, 768 (D.C. Cir. 1965). And so it is, as is the role regarding non-defendant witnesses' prior convictions. Though Congress debated long and bitterly about adopting a rule that incorporated a doctrine that they had only recently rejected in other legislation, it eventually compromised, ultimately putting the screen back in place. Gainor, supra note 37 , at $770-76$.

Motions to exclude impeachment under Rule 608 or 609 are frequently made in limine. If the ruling is adverse to the defendant, he may elect to remain off the stand. However, the Supreme Court has held that his failure to testify will deprive him of appellate review of the ruling. Resolving a conflict in the circuits, Chief Justice Burger found-without dissent-that in order to assess the prejudice component, "the [reviewing] court must know the precise nature of the defendant's testimony, which is unknowable when, as here, the defendant does not testify." Luce v. United States, 469 U.S 38, 41 (1984). Even a proffer of testimony will not do, the Chief Justice noted, because actual testimony may differ from the proffer. $1 d$. at $41-42$. Although Luce involved impeachment under Rule 609 and Justice Brennan's concurrence suggested that the holding be limited thus, see id. at 43 (Brennan, J., concurring), appellate courts have had little difficulty applying it to Rule 608 impeachments as well. See, e.g., United States v. Weichert, 783 F.2d 23, 25 (2d Cir.), cert. denied, 479 U.S. 831 (1986).

53. The technical distinctions I am about to describe were not noted by the Advisory 
one, Rule 609 is cast affirmatively ("shall be admitted if . . ."), whereas Rule 403 is cast negatively ("may be excluded if ..."). From this, a different location of burden might be inferred: the impeaching party bears the burden of demonstrating superior probative value when the accused is the witness, whereas the impeached witness bears the burden of proving prejudicial overload in all other cases. Whatever sense this distinction may make in terms of pohicy considerations, it is almost certainly not read this way by trial courts, and if it were, the probative/prejudicial balance is probably not susceptible of the fine-tuning that a differential allocation of burden would require. Moreover, the lengthy Advisory Committee Note regarding the amendment does not specifically address the significance of this distinction.

So, too, a close reader of the text might argue that Rule 403, unlike Rule 609, employs the term "substantially outweighs" in describing the condition for exclusion of otherwise relevant evidence. From this, it might be inferred that a greater quantum of prejudice is tolerable when an ordinary witness is impeached by prior conviction than when the defendant himself faces discrediting. Again, the perceived distinction may be consistent with our general pohicy of special sensitivity to the hazards of defense, but the practical possibility of such fine calibration of the danger of prejudice is dubious. ${ }^{54}$

Finally, close readers may point to the other considerations enumerated in Rule 403 and ignored in Rule 609. In addition to the prejudice factor, there is the probity factor. Rule 403 provides that evidence may be excluded if probative value is substantially outweighed by dangers of "confusion of the issues, or misleading the jury, or by considerations of undue delay, waste of time, or needless presentation of cumulative evidence." From this imbalance, some might claim that the impeaching convictions might be excluded when offered against a witness other than the accused by operation of the distraction or delay factor, whereas a prior criminal conviction of the defendant will always be efficient. ${ }^{55}$ Apart from the possible answer that Rule 403's mefficiency consider-

Committee, who appeared to regard the balance of considerationis in Rule 403 as interchangeable with the language of Rule 609. See infra note 90 and accompanying text.

54. As will be seen below, neither of these textual variances is considered a significant difference by trial judges. See infra text accompanying note 90.

55. For the reactions of trial judges to these bases for distinction, see infra text accompanying note 89 . 
ations are superfluous (being subsuined in the concept of probative value ${ }^{56}$ ), such a construction of the distinction between defendantwitnesses and other witnesses would be inconsistent with the pohcy-advanced, arguably, by the preceding distinctions-that a higher standard should protect the testifying defendant in a criminal case against impeachment by prior conviction.

These "technical" distinctions between the language of Rule 609 and Rule 403 may be chimerical, unnoticed, and unintended-as I suspect they are. But they do not, in any case, obstruct the conclusion that the amendinent puts the shoe on both feet: Prejudice may be felt by either side from an attack on the character of its witness, and if that prejudice outweighs relevance, the impeaching evidence will be excluded. Ordinary canons of construction reinforce this conclusion. Substituting the word "accused" for "defendant" to remove all ambiguity, Congress moved the prejudice clause to a position where it obviously applies only to impeachment of the accused in a criminal case ${ }^{57}$ in that circumstance only, an impeaching conviction is excluded if its probative value on the issue of credibility is exceeded by its prejudice to the accused. Prosecution witnesses, then, are left free of the restrictive phrase; as to them-like defense witnesses and witnesses in civil cases-impeachment by prior conviction is "subject to Rule 403." However Rule 403 may differ from the simple balance stated in Rule 609 , this textual transposition can only mean that, in criminal cases, prosecution witnesses should be shielded from impeachment by prior conviction if revealing the prior conviction would result in prejudice to the prosecution.

Thus, according to this interpretation, the amendment of 1990 accomplished a substantial change. For the first time, the prosection may shield its witnesses from character attacks by prior convictions having little bearing on credence. The Advisory Committee appeared to recognize and approve of this new dimension to the test of prejudice-though it was not among the moving purposes of the amendment. They wrote:

Some courts have read Rule 609(a) as giving the government no protection for its witnesses. This approach also is rejected by the

56. Delay is not "undue," it might be argued, time is not "wasted," and data are not "needlessly cumulative" where the proffered evidence is truly probative.

57. For the present wording of Rule 609(a), see supra note 39. 
amendment. There are cases in which impeachment of government witnesses with prior convictions that have hittle, if anything, to do with credibility may result in unfair prejudice to the government's interest in a fair trial and unnecessary embarrassment to a witness....

The amendment applies the general balancing test of Rule 403 to protect all hitigants against unfair impeachment of witnesses. The balancing test protects civil litigants, the government in criminal cases, and the defendant in a criminal case who calls otler witnesses. 38

Thus, no longer will the jury assess the credibility of prosecution witnesses with their full list of derelictions in evidence while working with a purged and sanitized version of the defendant's criminal history. To many a federal prosecutor, forced to rely on an unsavory witness, this should coine as welcoine news.

However, notwitlistanding the seemingly clear textual support, there is a certain uneasiness about reading the provision as bilateral. First, the language seems studiously to avoid the obvious parallel construction of a rule intended to accord parallel conditions. More important, there remains a sense annong the judges and the practicing bar that the prosecution is not "prejudiced" by the criminal records of its witnesses in the same way that the defendant is. ${ }^{59}$ According to soine, so mucl more dire is the consequence of conviction to the defendant than the consequence of acquittal to the prosecution that a defendant deserves advantages whien he cliooses to tell his story from the stand, advantages such as relief from the baleful effect of his own criminal past. This arguinent does not impress me.

But the outstanding difference between harm to a defendant and harm to other witnesses is undeniable: $A$ jury might conclude from the testifying defendant's criminal career (despite vociferous instructions from the court to the contrary) that he cominitted the

58. Committee Note, supra note 45 , at 354 (citations omitted). The Note goes on, however, to take back much of the parity granted:

The probability that prior convictions of an ordinary government witness will be unduly prejudicial is low in most criminal cases. Since the behavior of the witness is not the issue in dispute in most cases [though it is in many], there is little chance that the trier of fact will misuse the convictions offered as impeachment evidence as propensity evidence. Thus, trial courts will be skeptical when the government objects to impeachment of its witnesses with prior convictions.

Id. at 354-55.

59. See supra text following note 99. 
crime charged because of a demonstrated propensity to engage in crimimal conduct. That kind and degree of damage cannot be suffered by the prosecution or its witnesses, however the jury might misapply the evidence of bad character. Given the potency of character as a gauge of conduct, concern for this seepage from secondary conduct (that is, propensity to lie under oath) to primary conduct (that is, propensity to commit the crime charged) is hardly misplaced. The odd contradiction between the rule allowing consideration of evidence of character for one purpose but not the other mvites misapplication of the data. ${ }^{60}$

\section{B. The Admissibility of Facts and Circumstances Underlying a Conviction}

The predicate for the permitted inference to mendacity is the character of the witness manifesting the relevant trait. The character of the witness may be the subject of testimony, but it may also be inferred from behavior revealing it. Thus, a witness might testify that the previous witness was generally thought of as untrustworthy or that the previous witness submitted a fabricated work record when he applied for a job. It seems obvious to me that, despite the traditional preference in the Rules for evidence of general reputation or personal opimion, specific evidence of conduct is more enlightening. Moreover, the more facts and circumstances surrounding the prior conduct that are available, the more mtelligently a jury can assess its significance on the only issue on which it is admitted: credibility. The proposition is especially true when the prior behavioral event is a criminal conviction.

A conviction is a datum of inescapable ambiguity. The name of the crime may be virtually meaningless (for example, RICO, or violation of the Hobbs Act), or it may be a gross designation that describes a variety of behavior (for example, violation of the Civil Rights Act, or mail fraud). Without evidence of the underlying conduct, about all the jury has to work with is that this witness has previously engaged in criminal behavior-not much, unless one subscribes to the ancient assumption from which the rule was

60. It should probably be noted briefly in passing that the status of defense witnesses other than the defendant is in some doubt. Whether, by association, the same sort of prejudice infects impeachment of the defendant's witnesses is uncertain. Is a jury likely to say that because the defendant consorts with criminals-at least to the extent of calling them to the stand-he probably committed the crime charged? Perhaps. 
born: Felons of all descriptions are forever afterward less truthful than other folk on any subject. But add some information about behavior to the datum and the fact of conviction may imply a piece of meaningful conduct from which inferences to mendacity may be reasonably drawn. Or the factual context of the conviction may weaken the link with testimonial mendacity that a jury might be otherwise tempted to draw. The question is: Do the Federal Rules allow amphifying facts?

Like Rule 405, which deals with proof of character generally, Rule 608 expresses uneasiness with evidence of the trait of mendacity or veracity found in specific syinptomatic instances of behavior. And Rule 609 provides quite clearly that only the fact of conviction is admissible for impeachinent. ${ }^{61}$ Rule 608(b), however, provides that specific instances of conduct, probative of "truthfulness or untruthfulness," may be "inquired into on cross-examination" of the impeached witness. The catch is that the language of Rule 608(b) appears to exclude, explicitly, instances of dishonest conduct that result in criminal convictions. It provides: "Specific instances of the conduct of a witness ... other than conviction of crime as provided in rule $609 \ldots$ may . . . be inquired into on cross examination of the witness ...."Facially, then, these rules taken together seem to inean that whereas unprosecuted frauds, rich in factual detail, may be the subject of impeachment by crossexamination, the same conduct resulting in conviction may be elicited only by evidence of the conviction itself, a nude datum that may give hittle hint of the dishonest conduct underlying the crime.

This reading of the rules obviously produces a foolish result. No good reason supports allowing extensive inquiry into an elaborate real estate hoax and the wituess's part in it as long as it was never prosecuted as a crime, but limiting examination of the prosecuted swindle to the fact of conviction of mail fraud or some lesser, bargained-for crime to which the defendant may have been allowed to plead guilty. Moreover, in the case of a defendant

61. "Evidence that a witness ... has been convicted of a crime shall be admitted . ..." Some courts of appeals, however, have allowed somewhat more than the bare fact of conviction; in United States v. Kimberlin, 805 F.2d 210, 234 (7th Cir. 1986), cert. denied, 483 U.S. 1023 (1987), for example, the court found "no plain error, if error at all" in the prosecutor's inquiry into just what false statement under oath had resulted in the defendant's prior conviction for perjury (the statement under oath to a grand jury was a false denial of selling LSD). 
seeking to impeach a prosecution witness, some courts have indicated that the constitutional right of confrontation may require the judge to allow more extensive cross-examination regarding underlying conduct, ${ }^{62}$ an implicit acknowledgment of the centrality of surrounding facts.

A wiser construction would be that Rule 608(b) is unaffected by Rule 609, and that the fact that the witness's dishonest conduct resulted in a criminal conviction does not diminish the right of the opposing party to cross-examine the witness about the conduct itself. In this reading, Rule 608 (b) is taken as a provision concerned only with the admissibility of extrinsic evidence; it provides that proof of specific instances of dishonest conduct may be adduced only from the mouth of the impeached witness himself. In this context, the troublesome words of Rule 608(b), "other than conviction of crime as provided in rule 609," would not be read to limit the license to conduct that does not underlie a criminal conviction, but rather to exempt proof of the fact of prior conviction from the ban on extrinsic evidence. ${ }^{63}$ This reading also accords with the Advisory Committee Note. ${ }^{64}$

62. See, e.g., United States v. Haimowitz, 706 F.2d 1549, 1559 (11th Cir. 1983).

63. Weinstem and Berger are somewhat imprecise and simplistic on this narrow point. Speaking of "conventional practice" and Rule 609, they note that extrinsic evidence may be adduced to prove "misconduct which has been the basis of a conviction"-not the fact of conviction alone, but the criminal misconduct. 3 WEINSTEIN \& BERGER, supra note 6, 608[5]. This is far from clear from the language or application of Rule 609 . They go on to note that the reason for the acceptance of extrinsic evidence under Rule 609 is that "[w]hen the bad conduct is the subject of a conviction, the need to prove the underlying behavior is absent and the ensuing possibility of confusing the jury and protracting the trial by the side issue of the witness' guilt is eliminated." Id. at 608-29. To this observer, it is hardly imconceivable that an impeached witness may claim that he did not in fact commit the acts for which he was convicted; nor does the entry of judgment preclude that challenge.

64. Minor editorial liberty is required to derive clear support from the Advisory Committee Note. By inserting the clarifying term "extrinsic" at appropriate places, the Note can be rendered quite helpful. It says:

[T]he present rule generally bars [extrinsic] evidence of specific instances of conduct of a witness for the purpose of attacking or supporting his credibility. There are, however, two exceptions: (1) specific instances are provable when they have been the subject of criminal conviction [extrinsically, that is, by the fact of conviction], and (2) specific instances may be inquired into on crossexamination of the principal witness or of a witness giving an opinion of his character for truthfulness.

....

Conviction of crime as a technique of impeachment is treated in detail in Rule 609 , and here is merely recognized as an exception to the general rule excluding [extrinsic] evidence of specific imcidents for impeachment purposes. 
A generous reading, inoreover, allowing juries to hear the most probative material-i.e., exactly what the witness did in the events that led to her conviction-would be consistent with a fine old New York case called People v. Sorge. ${ }^{65}$ Over forty years ago, Judge Stanley Fuld of the New York Court of Appeals wrote an opinion still often cited-sometimes for propositions not in the opinion $^{66}$ - on the issue of the scope of impeachment by cross-examination concerning specific acts of prior misconduct. Specifically as to the problem of underlying conduct, Judge Fuld had this to say:

Since a witness may be examined properly with respect to criminal acts that have escaped prosecution, there is no reason why indictment followed by conviction should proscribe inquiry as to what those acts were. A knowledge of these acts casts light upon the degree of turpitude involved and assists the jury in evaluating the witness' credibility -all the more so in a case such as the present where conviction of a crime such as practicing medicine without a hicense gives no inkling whatsoever of the acts upon which the charge and conviction against defendant had been predicated. ${ }^{67}$

Insofar as Judge Fuld correctly stated the common law, these words may assist in interpreting the mismatched language of the rules. We have little other guidance. The commentary to Rule 608, while taking note of the decision, rejects it-but for an entirely different proposition. ${ }^{68}$ And federal appellate courts have said

FED. R. EVID. 608 advisory committee note.

65. 93 N.E.2d 637 (N.Y. 1950).

66. Most notoriously-and, for our purposes, disconcertingly-it was miscited in the Advisory Committee Note to Rule 608(b).

The other two points that Judge Fuld did make were: (1) a cross-examiner cannot be "fobbed off" by the witness's denial of the prior misconduct, but may pursue it with further questions asked in a good-faith effort to dislodge the denial; and (2) the similarity of the prior crimes to the one on trial (illegal abortions) and their number does not put them beyond the prosecutor's reach. In Judge Fuld's oft-quoted phrase, "Entitled to delve into past misdeeds, the prosecutor may not arbitrarily be shackled by the circumstance that the defendant has pursued a specialized field of crime and has committed many offenses." Id. at 639.

67. Id. (citations omitted).

68. The Advisory Committee Note states that the final sentence of Rule 608(b) is a "rejection" of Sorge to the effect "that any past criminal act relevant to credibility may be imquired into on cross-examination, in apparent disregard of the privilege against selfincrimination." FED. R. EVID. 608(b) advisory committee note. Perhaps the phrase "apparent disregard" signifies a reading between the lines of the Sorge ruling. But the opin- 
little about the Sorge principle. ${ }^{69}$ The few opinions of the federal district courts (all from the Southern District of New York) provide no basis to conclude that the principle articulated by Judge Fuld governs federal interpretation of impeachment-or that it does not. ${ }^{70}$

Another theory miglit be floated. It might be argued that the 1990 amendinent of Rule 609(a), by dropping the requirement that prior convictions inust be proved from the "public record," enlarged the source of evidence by which the "crime" of conviction miglit be established. If the tern "public record" is narrowly read (as it probably should be) to refer to clerks' entries, little beyond the name of the recorded crime can be offered. But if extrinsic evidence of conviction of a crime may now be adduced from various reliable sources, such as the prosecuting attorney who obtained the prior conviction, more detail concerning the "crime" may be efficiently adduced.

This theory must, at this point, be regarded as wholly speculative. The anendment is still too recent to be tested for scope. It is early even to guess whetlier trial judges will allow the fact of conviction to be proved from sources other than public records. And the additional expansion to define crime in terms of conduct will surely be considered raslı by some. Yet, the thought may offer

ion itself says nothing about implicit waiver of the privilege by testimony, and Judge Fuld's ruling could as easily be read to apply to cases in which the privilege is not asserted or not applicable to a question regarding prior convictions or their underlying facts.

69. Appellate courts frequently approve trial decisions to admit impeachment by prior similar offense, a tacit endorsement of one of Judge Fuld's conclusions. Still, practice is far froun uniform. Compare United States v. Sanders, 964 F.2d 295, 297 (4th Cir. 1992) (reversible error to admit prior conviction without determining as a prerequisite that probative value outweighs prejudicial effect) with United States v. Perkins, 937 F.2d 1397, 1405 (9th Cir. 1990) (no abuse of discretion in allowing impeachment of defendant by prior robbery conviction). In United States v. Browne, 829 F.2d 760, 763-64, (9th Cir. 1987), cert. denied, 485 U.S. 991 (1988), the appellate court found no abuse of discretion in allowing impeachment by a prior robbery conviction of a defendant accused of bank robbery. The trial judge had properly weighed the considerations, found credibility crucial, and determimed that the probative value of the conviction outweighed its considerable potential for prejudicial inferences of propensity. "Many courts, however, continue to admit evidence of prior conviction of violent crimes, sex crimes, and drug offenses for purposes of impeachment, even though the prior offense is similar to the crime charged, and often without any on-the-record balancing of probative value against prejudicial effect." Gainor, supra note 37, at 767 (footnote omitted).

70. See, e.g., Stephens v. LeFevre, 467 F. Supp. 1026, 1028-29 (S.D.N.Y. 1979); Independent Prods. Corp. v. Loew's, Inc., 22 F.R.D. 266, 273 (S.D.N.Y. 1958). 
a glimmer of hope for those (like the author) who long to imbue with some probative content the foolish anachronism of impeachment by prior conviction.

\section{Concerning the Probative Value of Criminal Conduct That Does Not Entail "Dishonesty"}

Rule 608 and Rule 609 both specify that evidence of character or prior conduct is admissible only if relevant to the trait of truthtelling. Rule 608 uses the term "truthfulness or untruthfulness" either as a trait of character or as a fair inference from particular behavior (as the court, in its discretion, interprets it). Rule 609 is a bit more complex, and obscure.

Rule 609(a)(2) speaks of crimes (of any grade) that involve dishonesty or false statement. ${ }^{71}$ The notes recall the common law category of crimen falsi and cite as examples offenses like perjury, fraud, and embezzlement, in which a false representation is a definitional element. ${ }^{72}$ If Rule 609(a)(2) is so sharply limited, few offenses will fit the bill since falsehood is a comparatively rare element, at least among the common law catalogue of crimes. Even the crime of embezzlement is, in many jurisdictions, ${ }^{73}$ no more than a special case of larceny, a crime that carries no element of falsehood.

71. A semantic stickler might argue that "dishonesty" and "untruthfulness" are not linguistically congruent. Here, however, the thought is that the commission of a crime involving dishonesty reveals a character trait that inclines the actor to that special variant of dishonesty known as lying.

72. FED. R. EVID. 609 advisory committee note. For a sample catalogue of typical state crimes, see 3 WEINSTEIN \& BERGER, supra note 6, I 608 [5], at 608-46. At common law, crimes of "stealth" were included as bearing on veracity. Thus, shoplifting and burglary would be relevant though not, strictly speaking, crimes involving dishonesty. Some dispute continues regarding this category. 3 WIGMORE, supra note $15, \S 982$. Gamor maintains, at one point, that "federal courts now generally agree... that 'dishonesty' as used in Rule 609 is a term of art, encompassing only crimes that include an element of deceit, untruthfulness, or false statement." Gainor, supra note 37, at 777 . A few sentences later, however, he notes that "[t]he federal circuits disagree, however, as to whether 'dishonesty or false statement' includes such crimes as burglary, larceny, shoplifting, and narcotics offenses." Id. at 778. In the balancing process, Gainor reports, the appellate courts "give such great weight to the probative value of prior felony convictions that [they] are likely to uphold nearly any trial court decision to admit a prior felony conviction for impeachment-no matter how great the prejudice to the defendant." Id. at 780.

73. See, e.g., N.Y. PENAL LAW §§ 155.05, 155.25, 155.30, 155.35, 155.40, 155.42 (McKinney 1988). 
Again, a more generous reading is available. I do not dwell on the possible construction that all criminal conduct involves dishonesty in some sense of the term; indeed it is rather whimsical to assert that impersonating a pohice officer or writing a bad check is "dishonest," whereas burglary, robbery, rape, and inurder are not. Curious though it inay be, the law appears wedded to the division between honest and dishonest crimes, so I leave it alone.

Rather, I suggest that a reasonable interpretation of the word "involve" could connote the means of commission of a crime rather than the elements of its definition. ${ }^{74}$ Thus, any crime, including burglary and larceny, though boasting no generic element of fraud, inight "involve dishonesty or false statement" if the means by which the crime was committed entailed some misrepresentation-for exainple, the burglar obtained entrance by falsely identifying himself as a window washer, or the thief stole her employer's funds by subinitting false vouchers. ${ }^{75}$

Expanding the category of impeachinent crimes beyond the short list of crimen falsi accords with the governing concept of relevance: The behavior of the individual in coinunitting the crime reveals a trait of character from which the inference of testimonial mendacity inay be reasonably drawn. If anything, it is the actor's behavior that supports the inference, not the statutory definition of the crime. At the same time, the expansion requires the court, and perhaps allows the jury, to look beyond the name of the crime

74. In United States v. Forero-Perdomo, No. 90-1034, 1990 U.S. App. LEXIS 17617 (1st Cir. Sept. 24, 1990), the court, in reviewing a ruling on a prior conviction for smuggling, noted that it could not determine whether the crime "involved dishonesty or false statement" within the meaning of Rule 609(a), since it did not know "the manner in which the smuggling was accomplished." Id. at *4.

Weinstein and Berger note that "[a] number of courts have suggested looking to the underlying act rather than the title of the offense ..." 3 WEINSTEIN \& BERGER, supra note 6, q 609[4], at 609-52. But, they contimue, this would be a mistake; "[t]he statutory definition should control." Id. at 609-53. The wisdom of their conclusion is neither self-evident nor universally recognized. See, e.g., United States v. Carroll, 663 F. Supp. 210, 213 (D. Md. 1986) (refusing to "simply categorize particular offenses" as admissible for purposes of impeachment); see also United States v. Amahia, 825 F.2d 177, $179-80$ (8th Cir. 1987) (upholding trial judge's decision to permit extensive questioning about details of defendant's prior conviction for fraud after defendant had admitted the conviction and attempted to explain and minimize its significance).

75. Weinstem and Berger would disagree on the grounds that this area of the law demands mechanical rules for the sake of convenience: Requiring the judge to delve into the details behind the conviction is not convenient. 3 WEINSTEIN \& BERGER, supra note 6, I 608[4], at 609-53. And I cannot deny the cost. 
(and the definitional elements that go with the name) to the facts of the criminal transaction.

This shift of focus introduces major problems, even the specter of imsoluble doctrinal conflict. Although by general common law definitions it might not be altogether clear whether forgery or conspiracy contain basic elements of misrepresentation, reference to the local statute should resolve the question. But if "involving dishonesty" means "effected by deception," the qualification of the impeaching conviction will have to be determined by examining the evidence underlying the conviction.

Clearly, the question of whether conduct of commission may be a source of the "dishonesty" that automatically allows use of the conviction for impeachment is an important determination. Under this interpretation, many crimes that presently are not on the automatic admission list ${ }^{76}$-from shoplifting to inurder, and including rape, robbery, burglary, and larceny-might be added. At the same time, introduction of underlying facts may benefit the defense by reducing the onus of conviction and extenuating the culpability of the defendant. ${ }^{7}$

Resolving the uncertain meaning of the limiting phrase "involve dishonesty" is not an end to the matter. While Rule 609(a)(2) allows such evidence, 609(a)(1) allows any evidence of a prior felony upon a deterinination that probative value (on the issue of credence) outweighs prejudice. ${ }^{78}$ The only way to read

76. See United States v. Sellers, 906 F.2d 597, 603 (11th Cir. 1990) ("It is established in this Circuit . . . that crimes such as theft, robbery, or sloplifting do not involve 'dishonesty or false statement' within the mearing of Rule 609(a)(2)."); see also United States v. Barnes, 622 F.2d 107, 109 (5th Cir. 1980) (prior shoplifting conviction not probative of truthfulness).

77. Leading treatises disapprove of reference to the facts underlying criminal convictions to determine the admissibility of such impeachment evidence. Weinstein and Berger put it this way: "A number of courts have suggested looking to the underlying criminal act rather than the title of the offense in ascertaining admissibility . . . . But it is a mistake for the trial court to have to go behind the conviction to determine its details. The statutory definition should control." 3 WEINSTEIN \& BERGER, supra note 6,7609 [4], at $609-52$ to -53 . McCormick states that the prevailing-and more reasonable-practice is to allow no questions beyond the name of the crime, the time and place of conviction, and the punishment. The treatise goes on, however, to note with approval that a "substantial number of courts" permit the impeached party a brief statement of explanation or exculpation-a "harmless charity" according to Wigmore. MCCoRMICK, supra note 11 , 42 , at 152; 4 WIGMORE, supra note 15, \& 1117, at 251.

78. See, e.g., Amos v. Minnesota, 849 F.2d 1070 (8th Cir.), cert. denied, 488 U.S. 861 (1988) (prior convictions for robbery and aggravated rape allowed to impeach defendant's testimony in prosecution for inurder). 
these two provisions is that there are some crimes that reflect on a witness's penchant for falsehood but that do not involve dishonesty. ${ }^{79}$

One of the mysteries lurking beneath the surface of Rule 609 (a) is that if these prior felony convictions involve no dishonesty (even in the expansive reading of "involve" favored by many judges-and by me), then wherein lies their probative value? What forms of felonious conduct (committed within the preceding de$\mathrm{cade}^{80}$ ) can amount to evidence of a mendacious personality, revealing a person who, even as a happenstance eyewitness to a stranger's crime, would be more likely to lie under oath about it than a person without such a history? And where the impeached witness happens to be the defendant in a criminal case, are there honest felonies so probative of propensity to lie under oath that the manifest danger that a jury might consider a criminal record as evidence of propensity to coinmit the crime charged-the very essence of prejudice-is overcome? And what if that prior felony conviction-for homicide, let us say-is being offered agamst a defendant who is currently accused of homicide, a case where the danger of prejudice-by-inference-of-propensity is particularly acute $?^{81}$

Virtually the only quality I can imagine that might conceivably bring a shooting or a drug conspiracy into the positive probative value column is the aggravated nature of the crime. This theory, explicit in some state jurisdictions, ${ }^{82}$ is that a felony might be so

79. For a particularly generous reading, see United States v. Kinslow, 860 F.2d 963 , 968 (9th Cir. 1988), cert. denied, 493 U.S. 829 (1989), an aggravated kidnapping and rape prosecution, where the court of appeals found no error in allowing the prosecution to impeach the defendant's testimony with evidence of a prior conviction for armed robbery, a crime involving (the court found) "dishonesty." See also United States v. Barnes, 622 F.2d 107 (5th Cir. 1980) (approving of cross-exainination concerning a prior conviction for the possession of heroin); Gainor, supra note 37, at $767 \mathrm{nn} .23-24,26-27$.

80. FED. R. EVID. 609(b).

81. At least one appellate court, in reversing the trial judge, has recognized the danger of this possibility:

[W] here ... the prior conviction is sufficiently similar to the crime charged,

there is a substantial risk that all exculpatory evidence will be overwhelmed by a jury's fixation on the human tendency to draw a conclusion which is imper-

missible in law: because he did it before, he must have done it again.

United States v. Wallace, 848 F.2d 1464, 1473 (9th Cir. 1988) (quoting United States v. Bagley, 772 F.2d 482, 488 (9th Cir. 1985), cert. denied, 475 U.S. 1023 (1986)). For contrast, one might recall Judge Fuld's dictum in People v. Sorge, 93 N.E.2d 637 (N.Y. 1950). See supra note 66.

82. Weinstein and Berger note and discuss some of the cases in which a serious 
serious-a particularly brutal or cold-blooded murder, for example-that it reveals a gross disregard for moral obligations such that a factfinder might reasonably find character so warped that veracity is affected. ${ }^{83}$

I should emphasize that I do not espouse the notion that murderers are more mclined to try to obtam their acquittal by lying than are street-level dope pushers. Although the consequence of conviction is surely more severe for the murderer and the depravity of his soul perhaps more deep, I am convinced that the person accused of the lesser offense shares to the fullest the murderer's fervent desire for acquittal, just as both share fully the desire of the counterfeiter to procure his release by perjury if necessary and possible.

And when the theory is applied to the credibility of witnesses other than the defendant, its rationality becomes even more attenuated. Is the victim of a robbery who was previously convicted of an unrelated rape more likely to lie about how he was robbed than a victim who was previously convicted of simple assault? Is an eyewitness to that robbery more likely to be telling the truth about the identity of the robber if she was previously convicted only of possessing a small quantity of drugs than if she had been convicted of a vehicle homicide while driving intoxicated? The seriousness augmentation of the honesty standard brings the effort of the law to control impeachment-by-character into the realms of the absurd.

prior conviction was admitted, and the ruling sustained, though the crime in question had little direct bearing on the trait of veracity. 3. WEINSTEIN \& BERGER, supra note 6 , I 609[12].

83. In People v. Sandoval, 314 N.E.2d 413, 417-18 (N.Y. 1974), for example, the New York Court of Appeals stated:

Evidence of prior specific criminal, vicious or immoral conduct should be admitted if the nature of such conduct or the circumstances in which it occurred bear logically and reasonably on the issue of credibility .... To the extent, however, that the prior commission of a particular crime of calculated violence or of specified vicious or immoral acts significantly revealed a willingness or disposition on the part of the particular defendant voluntarily to place the advancement of his individual self-interest ahead of principle or of the interests of society, proof thereof may be relevant to suggest his readiness to do so again on the witness stand. A demonstrated deternination deliberately to further selfinterest at the expense of society or in derogation of the interests of others goes to the heart of honesty and integrity. 


\section{The Disposition to Lie Under Oath}

The theoretical discontinuity perpetuated by Rule 609 is a major wrench to reason: No inference to the primary behavior at issue inay be based on the predisposition of character, but disposition to lie under oath may be inferred from a variety of prior convictions. If anything, this ancient precept of the law of evidence is the reverse of common experience. Resolution of the question of whether a criminal defendant committed the bank robbery charged is materially assisted by knowledge that he robbed several others just like it-he has the personality to which that sort of conduct belongs. Knowing his predatory character and penchant for banks, a jury could reasonably find an elevated likelihood that the defendant as coinpared with the world at large coinmitted the act in issue. But the issue of whether a person (criminal defendant or other) is lying on the witness stand is very slightly illuminated, if at all, by data that the person had, on a previous occasion, misappropriated rent receipts. Testifying as a witness is such rare behavior, the trial such a unique occasion, that the honesty or dishonesty of the witness's testimony cannot be said to be consistent with a pattern of predictable behavior. Sinply put, it is extremely unlikely that any person testifies dishonestly because of a trait of dishonesty manifested by dishonest behavior in other, very different, circuinstances.

In my view (to state it bluntly), nearly all people choose to lie on the witness stand according to two determinants: the importance to them of having a falsehood believed and their confidence that their false testimony will achieve that end with ininimal risk. In this latter consideration, we may put the witness's security in his skill as a dissimulator along with his perceived impeachability by inconsistent evidence. Innocent defendants in criminal cases will of course tell the truth insofar as it promotes acquittal. But even they will lie or oinit facts where the full truth would heighten suspicion: Did she have a fight with the deceased a week before the murder? Was he in the store shortly before the robbery? All guilty defendants who choose to testify will lie on the stand about anything that might improve their chances and about which they imagine they can be persuasive. For virtually all-novice and experienced criminal-acquittal is the overriding, intensely desired, goal, and the risks of perjury are minimal. ${ }^{84}$ Victims of crimes

84. Not only are witnesses rarely prosecuted for perjury, but criminal defendants are 
and other witnesses in civil and criminal cases may also have diverse, if less pressing, interests in promoting some falsehood. Some open or secret affiliation with a party or syinpathy with the party's position; a desire to portray herself as more perceptive, heroic, or less forgetful; or (notably in the case of police officers) a need to describe greater diligence or inore faithful adherence to law or rules - these and a host of other interests may incline a witness, otherwise honest and law-abiding, to shade the truth.

There are undoubtedly some, perhaps even a sizable nuinber, of folk who will scruple to lie under oath for moral or religious reasons. As guilty defendants, these people perhaps will choose not to testify. ${ }^{85}$ Ordinary witnesses, subject to subpoena, have no such option. They will try to tell the truth, the whole truth, and nothing but the truth when their interest in proinoting a falsehood is no stronger than their scruple. But raise the stakes (say a beloved child needs an alibi) and increase the certainty of impunity (it's only her word against mine), and even people who pride themselves in their honesty will either take their chances with perdition or convince themselves that their lies are true. Compared with the strength of these determinants, the prior history of honest or dishonest behavior in a variety of unrelated circumstances is of marginal significance.

This is not to say that the two operative factors-interest and confidence in promoting the lie-have constant weights across the population of witnesses. Detachment (the counterweight to interest) is a more significant element of self-esteem in some people, and sociopathy or previous success with falsehood may bolster the belief of others that their lies will escape detection and persuade. To some sinall extent, this variability of weights may support the relevance of evidence that a witness is an experienced liar. But compared to the significance of the instrumental factor of interest (i.e., a witness's need to have the falsehood believed), and consid-

virtually exempt (which they doubtless know). If convicted, their fruitless perjury may induce some judges to add a small merement to their sentence; if a defendant is acquitted, only the most vindictive prosecutor will take a second shot at proving his lost cause by the perjury route. The barrier is not the Double Jeopardy Clause, but rather the prudent balance of discretion and valor.

85. It is hard for me to imagine a guilty person who, for reasons of conscience, would decline to furnish false exculpatory evidence that he thought might procure his acquittal. But this may reflect my limited exposure to the scrupulous criminal set; perhaps there are some who fit this description. 
ering the wide range of reputed liars, the effect of evidence of character for veracity or mendacity on the probability of falsehood is minuscule.

There is one line of reasoning by which certain prior convictions can be made truly relevant to testimonial veracity. But it is decidedly a bootleg inference, and (unlike the Federal Rules) it applies only when prejudice is highest-when the witness is a criminal defendant and the prior crime is very similar to the charge on trial. By ordinary probability-and contrary to the Rules of Evidence-a person who has previously committed a certain type of crime is more likely to have committed another like it than a person who has not. One street inugger may be no more likely than another to have committed the inugging charged. But, by the laws of personality and beliavior, eitlier is substantially more likely to liave committed the mugging in question than a person drawn at random from those who have never committed a robbery. And the inore probably guilty person (viz., the one with the record) who gives exculpatory testimony is more likely to be lying than is a more likely innocent person, since truthful testimony will help acquit the innocent but will surely convict the guilty. Thus, testifying criminal defendants with records, especially for the same sort of crime, are inore likely to be lying on the stand than those witlout records, because they are more likely to be guilty.

But lowever this line of reasoning may accord witl logic and experience, it is utterly repugnant to basic premises of the trial process. Adamantly excluding direct use of evidence of propensity, this dogma would never tolerate indirect use of evidence of propensity by an inference to self-protective perjury. Moreover, discrediting the exculpatory testimony of the one felon on trial may convict him on evidence that offers no basis whatsoever for selecting lim over thousands of others witl similar records.

\section{THE FEDERAL RULES OF EVIDENCE AND THE TRIAL BENCH}

Because of the importance of Rules 608 and 609 as the source of instruction to jurors on how to read credibility in cliaracter and because of several latent ainbiguities in these rules, I surveyed three hundred judges of the United States District Courts, with at least three years of bencli time in the federal courts, calling for 
their interpretation of and practice with respect to these Rules. ${ }^{86}$ Essentially, I asked them about three aspects of the rules: (1) the ingredients of prejudice requiring exclusion of evidence of a witness's prior convictions; (2) finding probative value in prior convictions, both in the dishonest and the honest varieties; and (3) the problem of allowing evidence of specific conduct suggesting an honest or dishonest character. I received sixty-eight replies, a response rate of almost twenty-three percent, for which I am grateful in view of the fact (as several judges informed me) that judges are inundated with questionnaires and most habitually decline to participate in surveys. ${ }^{87}$ I do not promulgate these results as statistically representative of the understanding or inclinations of the federal trial bench as a whole. They are only what they are: the thoughts of a significant number of experienced district court judges who cared enough about the project to submit data. The results, however, are sufficiently dramatic to be instructive on the issue: Do the Federal Rules provide a rational and uniform scheme for the rulings by trial judges on important evidentiary questions affecting credibility?

86. The results of the survey may be found infra Appendix A. I readily acknowledge what readers may notice at once: The questions are framed in terms that could easily have been understood differently by different judges, as, for example, by the interpolation of various conditions. Hence, what appear to be sharp divisions in opinion might merely be the result of different readings of the questions. Unfortunately, the difficulty of inducing response to a mailed survey precluded finer or more extensive calibration.

87. These are hardly the only reasons judges failed to respond. One judge wrote that he was not "comfortable" checking "alternatives." "Judges," he wrote, "do not like absolute categories." Several found the questions "unclear" or not sufficiently "precise" and one reported the "impression that the foregoing questionnaire was designed by a visitor from another planet." Many reported little experience-which in one case was attributed to the ignorance of trial counsel who rarely objected to evidence on these grounds. One judge noted, "In my 12 years I have rarely had a difficult question regarding application of FRE 608 and 609. My experience is therefore too limited to enable me to comment intelligently on problems experienced by these rules." Another wrote, "Notwithstanding a heavy criminal docket, I do not recall a problem arising with impeachment based on a prior criminal record." And one judge lectured me thus:

Trial judges are not free to do whatever they would prefer or like, but must follow governing authority in [theirl circuit. Therefore, this research is of limited value except for judges that don't pay much attention to governing authority. Congress and law professors really don't care much what trial judges think; maybe that's why so few judges took the time to answer this questionnaire ..... It tends to take a while, if the answers are thought about. It seems silly to take the time to answer something of such inconsequence. 


\section{A. Prejudice from Impeachment as a Two-Way Street}

Rule 608, it will be recalled, discloses no distinction whatsoever between the impeachment of witnesses for one side or the other. Prior to its amendment, Rule 609(a) made no overt distinction, but its "prejudice to the defendant" language implicitly allowed any prior conviction to impeach a prosection witness; the recent amendinent of this provision (though arguably directed at the confusion on the civil side) technically separates criminal defendants from all other witnesses-but the substantive effect of the distinction is elusive. ${ }^{88}$ Since text and coinmentary provide no relief of these uncertainties, I sought information on practice, surmismg that the issue is so commonplace that some uniformity must have developed ainong the trial courts. Did they, do they, sanitize the history of prosecution witnesses as they do the defendant's and possibly his witnesses'?

As a prelininary matter, I tried out the notion that the amendment of Rule 609 preserved certain distinctions by incorporating Rule 403 for ordinary witnesses while specifying a probity-prejudice balance for testifying defendants. Only eight judges registered agreement with the proposition that the distinctions in the impeachment of criminal defendants and other witnesses that are appropriate following the amendment of Rule 609 are: (1) confusion and inefficiency factors may not be considered when the witness is the defendant, and (2) prior convictions should be excluded to impeach an ordinary witness only where the prejudice would be "substantial." 89 I am tempted to say that the judges' overwhelming rejection of this idea confirms my own belief that the apparent textual variance between the language of Rule 403 and the probativity/prejudice diclotorny pure and simple in Rule 609 conveys no real difference in the admissibility of impeachment evidence as between testifying criminal defendants and other witnesses. ${ }^{90}$ However, only three judges declared that they intended to "disregard" the purported distinctions since they are "technical

88. See supra Section II(A).

89. Judicial Survey I, infra Appendix A, Question 1.

90. This reading is consistent with the Advisory Committee Note on the amendment, which observes, "The amendment applies the general balancing test of Rule 403 to protect all litigants against unfair impeachment of witnesses." Committee Note, supra note 45 , at 354 . Whether incorporated by reference or spelled out in abbreviated form, the balancing process is the same. 
(if not inadvertent)." ${ }^{91}$ Twenty judges went on to say that, since these distinctions are "evident in the text," they would atteinpt to observe them..$^{2}$

Directly confronting the issue, I asked the judges whether they had previously observed a distinction for these purposes under either rule or expected to alter their practice in light of the change of law. ${ }^{93}$ Twelve replied that they had regularly, frequently, or occasionally distinguished between criminal defendants and other witnesses, but no longer believed such distinctions appropriate in light of the amendinent of 609 (a) ${ }^{94}$ This group-the sinallest by a wide margin - had a reaction closest to what I deem the correct interpretation. Though it is difficult to understand why only four said they "regularly" did what the old rule clearly required in every case (viz., consider only prejudice to the defendant), they perceived the evident effect of the amendment to allow other witnesses' records to be filtered through the probity-prejudice test of Rule 403.

Twenty-three judges replied that they had made no such distinction previously and did not believe the amendment required any change in their practice. This sizable number $33.8 \%$ of the total responding) - who indicated that, for purposes of Rules 608 and 609 , they had never distinguished between defendants and other witnesses in criminal cases-must have done one of two things: Either they invariably failed to exclude as prejudicial any felony convictions on defendants' rap sheets (which seeins unlikely), ${ }^{95}$ or they gratuitously read into Rule 609 a prejudice-to-theprosecution clause and filtered the records of prosecution witnesses as they did defendants' records. (I had thought such reciprocity unheard of). ${ }^{96}$

91. Judicial Survey I, infra Appendix A, Question 1.

92. Id. Perhaps some of my respondents were merely affirming their good faith efforts to apply, where possible, apparent drafting choices, however meaningless.

93. Id.

94. The division was: 4 said "regularly," 3 said "frequently," and 5 said "occasionally." Id.

95. Perhaps, as one of my colleagues suggests, many judges simply ignore the Rules and adhere to the common law rule allowing all witnesses to be impeached by proof of any felony conviction.

96. It is also possible that these judges misunderstood the question, though I would have thought it was clear enough. See Judicial Survey I, infra Appendix A, Question 1. 
Thirty-five judges-the largest group (51.5\%)-said that they had always weighed the prejudice factor "more heavily" when the witness was the accused in a criminal case, and, "notwithstanding the amendment of Rule 609," they expected to contimue to do so. ${ }^{97}$ How should this reaction be received? When performing the balancing test under either Rule 609(a)(1) (as amended) or Rule 403 , the judge has considerable discretion and it would hardly be an abuse to consider the peculiar jeopardy of the defendant when assessing the impact of prejudice. And it would be unfair to infer from their responses to this question alone that this group of judges is generally disinclined to purge any felony conviction from the record of a prosecution witness. "Weigh more heavily" may mean only "consider more carefully" or "screen out the more doubtful convictions more readily." Such a reading, in view of the heightened prejudice potential for defendants, might seem reasonable. But an additional question puts that interpretation in some doubt. I asked the judges whether they believed that the amendment had no effect whatsoever on impeachment of witnesses in criminal cases, asking, in effect, whether prejudice should still be weighed as potential damage to the defense only. Thirty replied affirmatively. Ten disagreed and twenty-eight registered no opinion. ${ }^{98}$ Thirtynine judges went on to say that, to the extent that the amendment had made no change in prior law regarding the impeachment of prosecution witnesses by their prior convictions, the legislative decision had been wise; only four said they regretted that Congress had missed the opportunity to change the rule. ${ }^{99}$

The proportion of responding judges (3-1) who recognized no secondary effect of the amendment on criminal cases is somewhat perplexing. The clue, perhaps, is in the even larger number (and overwhelming majority) who expressed approval of the former rule by which the prejudice filter belonged exclusively to the defendant. ${ }^{100}$ It is therefore probably fair to read this datum as indicative of an overriding sentiment among the judges that notwith-

97. Id.

98. Id. Question 9.

99. Id. Question 10.

100. Id. Question 1. This datum, incidentally, sits uncomfortably with the substantial number of judges who, answering my previous question, said they never distinguished between defendants and other witnesses under the superseded version of Rule 609. 
standing the ostensible parity provided by the amendment, prejudice still runs predominantly one way.

It is quite possible that judges find it difficult to conceive of prejudice to the prosecution from the impeachment of a government witness. Apparently, most of the judges, unlike the legislators, continue to insist that the government suffers no "prejudice" if the jury figures its felon-witnesses "deserved what they got" (if they were victims) or are "such bad actors they probably did the crime they claim to have witnessed" (if mere observers). Nor are these judges mclined to regard the possibility of an unjust adverse verdict as "prejudice" when suffered by the prosecution. This means that the prosecutor, hoping to shield her co-conspirator cum government witness from impeachment by prior conviction, will have a harder job persuading the judge to find prejudice than defense counsel would have in the same circumstances-if indeed she is lucky enough to draw a judge open to persuasion. Except for the few judges who are prepared to recognize that prejudice includes the unwarranted defeat of a prosecution, with its harm to the government and pain to the discredited victim, along with the more visible penalty of conviction, the trial bench seems inclined to nullify a major aspect of the amendment of 1990 .

Perhaps this is as it should be; perhaps the judges are right that balanced burdens are not always the mark of justice. There is both reason and tradition behind this disproportionate sensitivity. But such regular use of discretion does seem to run against the congressional purpose to put defense and prosecution witnesses, each encumbered by the same record, in similar jeopardy with regard to impeachment. And to many, it is inappropriate that judicial disposition persists unaffected by a plain legislative change in the provisions of the governing rule.

In suin, perhaps more troublesoine than any particular disagreement between the branches on the impeachability of sullied witnesses is the variety of judicial readings of the rules. If we expected the law of evidence to provide any consistent help to a jury wrestling with the character/credibility issue, or at least a predictable set of parameters by which the gaine will be played, this candid snapshot of courtroom practice has to be disturbing. The judges are distributed across a wide spectrum, and, as a consequence, the measured judgment reflected in the rules is replaced by the chancy business of individual inclination. 
B. Contextual Facts and Circumstances to Amplify an Impeaching Prior Conviction

Rule 608(b), which allows evidence of conduct probative of veracity to be elicited on cross-examination, may be read to exclude conduct that underlies a criminal conviction. ${ }^{101}$ Or the two sentences of the rule may be construed to allow extrinsic proof of such relevant conduct only by the fact of conviction. I asked the judges whether they allowed evidence of the specific acts and circumstances underlying a criminal conviction to be adduced by and from the impeached party. ${ }^{102}$

Where the court has allowed impeachment by proof of a prior conviction under Rule 609, seventeen judges said they never allow the impeached person to give the underlying circumstances "by way of explanation or extenuation." Nineteen said they regularly did so. Twenty-six said they "sometimes" did so. To amplify the "probative significance" of a conviction, thirty-six judges replied that they never permitted the impeaching party to adduce underlying circumstances, whereas twenty-six do so either regularly (so say six) or sometimes (so say twenty).

Where the court has disallowed impeachment under Rule 609, forty-one judges will never allow the specific acts underlying the conviction to be adduced under Rule 608(b) "insofar as they may be probative of veracity." Nineteen judges, however, checked "sometimes," indicating that they did not believe the disposition of the matter under Rule 609 necessarily controls the issue under Rule $608(\mathrm{~b}){ }^{103}$ Specifically, nineteen judges stated that they believe that Rule 608 is independent of Rule 609. ${ }^{104}$ More than twice that many (forty-two), however, endorsed the statement that Rule 608 should not be used "as a back door when the front door of Rule 609 has been shut."105

101. See supra text following note 61 .

102. Judicial Survey I, infra Appendix A, Question 7. Some appellate courts have allowed the facts underlying a conviction to be adduced responsively only. In United Stated v. Amahia, 825 F.2d 177, 179-80 (8th Cir. 1987), for example, the court approved extensive probing for details because the defendant, on direct examination, had sought to lighten the impact of his prior conviction. See also Umited States v. Wolf, 561 F.2d 1376, 1381-82 (10th Cir. 1977).

103. Judicial Survey I, infra Appendix A, Question 6.

104. Id.

105. Id. 
I queried my responding judges on the issue of whether the entire import of Rule 609 has to do with control of extrinsic evidence and found them to be almost evenly divided. ${ }^{106}$ Sixteen agreed, eighteen disagreed. Thirty-one had no opinion, noting that the question had "never come up."107 It came as a major surprise to me to learn that in nearly half of these trial courts of experienced judges the import of a central rule of impeachment had never arisen.

Of those who answered this question, the nearly even division is more understandable-the provision is insolubly ambiguous. ${ }^{108}$ To those who believe that Rule 609 addresses only the issue of the manner of proof, the entire issue of when and by what conduct character may be proved on the issue of veracity is thrown back on Rule 608. Rule 609's complexity, if nothing else, suggests it had a more ambitious purpose than to add to the extrinsic proofs allowed by Rule 608 (opinion and reputation concerning character), the fact of prior conviction where a specific act of misconduct eventuated in a judgment. Yet this construction accords with my general preference for inquiry concerning conduct regardless of adjudicated outcome. And one might wonder (I did not ask) what the opposing contingent believes was the purpose of Rule 609 beyond the narrow question of resort to extrinsic evidence.

\section{Honest and Dishonest Crimes Relevant to Testimonial Mendacity}

Evidence of crimes that "involve dishonesty," Rule 609(a)(2) provides, "shall be adinitted regardless of punishment." But what does the word involve mean? Are these only crimes with a definitional element of dishonesty? Or does the term encompass

106. Id. Question 8.

107. Id. Parenthetically, with regard to the "no opinion" group, I have mastered iny initial surprise at the number of notes I received to the effect that what seemed to me patent ambiguities regarding commonplace proof in criminal cases were as exotic as reported by the trial judges-all of whom had at least five years of bench time. Either criminal trials across the nation are rare compared with our local district, or the lawyering is oblivious to tactical opportunities accorded by mept codification, or quite possibly, the problems that perplex me are largely the product of academic imagination, dissipating at once on contact with the pragmatisin of the courtroom. Fortunately, I have sufficient responses to assume that, for some judges at least, the issues are real.

108. See supra Section II(B). 
all crimes committed by means of deception? And if so, how are the circumstances of commission to be adduced? ${ }^{109}$

I surveyed the judges on whether they would rate a crime as "dishonest" by its definition or the manner of its commission. ${ }^{110}$ Again, the survey reveals considerable disagreement on the issue among the judges responding. What one might have expected to be the general rule-strict regard for definitional elements-drew the fewest adherents. A heavy majority of fifty-four acknowledged that they considered "the nature and circumstances of the underlying conduct (in addition to the elements of the crime of conviction) in determining whether it is a crime involving dishonesty under FRE 609(a)(2)."111 Only fourteen indicated they never took conduct into account. Once again, one is forced to conclude that in the courtrooms a fundamental interpretation of the compass of a basic rule of impeachment is far from settled.

Apart from the additional element of uncertainty disclosed by these replies, one wonders what the majority relies on to obtain the necessary information concerning the evidence underlying the prior judgment. It is hard to imagine the court reading a trial transcript, holding a hearing that replays the prior trial, or relying on the word of the convicted person recounting just what he did in the commission of his prior offense.

In addition to dishonest crimes, the rule allows impeachment by evidence of conviction of crimes that are otherwise probative of testimonial veracity. The rules offer no hint of what aspect of a crime might render it relevant if it did not involve dishonesty even in the generous interpretation that most judges (and I) prefer. One possible candidate might be its àggravated nature. I inquired of the sitting judges whether they considered seriousness of a prior honest felony in deciding whether to allow it for impeachment. ${ }^{112}$ Eighteen said they always do; almost twice as many, thirty-four, said (mysteriously), "Sometimes"; and fourteen replied, "Never." Apparently, the significant majority believe that (at least in some cases) the likelihood of a testifying defendant's self-exonerating

109. See supra Section II(C).

110. Judicial Survey I, infra Appendix A, Question 3.

111. Twenty-five said "always," twenty-nine said "sometimes." Id. It is quite possible that the "sometimes" judges meant that they considered means of commission im cases where the prior conviction did not have an obvious element of fraud.

112. Id. Question 4. 
perjury rises with the seriousness of a prior criminal record more rapidly than the prejudice such a felon would suffer with a jury on the ultimate issue. Some courts have attempted to articulate a theory for admitting aggravated honest prior crimes on the issue of present mendacity. A person who has committed the brutal, multiple murders of which this defendant was convicted has demonstrated that he puts his own imterest ahead of his social obligations, and such a person might not scruple to lie under oath to secure his own acquittal in the crime on trial. ${ }^{113}$ It is a test of judicial temperament just to state this proposition with a straight face. Yet for some reason like that, nearly all judges appear to believe that the jury should hear about the witness's most serious prior transgressions even if such conduct has little if anything to do with the trait of truthtelling.

Presumably, in the small proportion of fourteen courtrooms where prior convictions are never weighed for gravity, the dishonest character of the prior offense is the sole determinant of relevance. Despite its disregard of the import of Rule 609, this seems to me the most defensible reading. If a prior conviction has any bearing on the issue of testimonial veracity, it must be because the conviction demonstrates dishonesty, not criminality.

\section{Postscript}

Becoming dismayed by the conclusions toward which this work was tending, I went back to the judges. I mailed a new survey to the district court judges who had responded to my first solicitation. ${ }^{114}$ Did they share my sense that in a large proportion of federal trials-especially criminal trials-the validity of the jury verdict was essentially unknowable? Did they regard credibility as a baffling and pervasive issue on which the conventional array of probes available to the jury performs fitfully at best? How well had their faith in the oath survived their experience with the eternally conflicting stories of witnesses?

Their replies can certainly be read as reassurance that, overall, the jury system works pretty well. Of those responding, sixty percent said they thought their juries had reached the correct verdict in ninety percent or more of the cases; and virtually all the rest

113. See supra note 83 and accompanying text.

114. Judicial Survey II, infra Appendix B. 
said they agreed with the result seventy-five to ninety percent of the time. ${ }^{115}$ Of course, those numbers can be read by pessimists in a quite different light: Some forty percent of our experienced federal trial judges think juries are wrong as frequently as one case out of four.

Not one judge registered agreement with the proposition that credibility is one of the most perplexing issues in a trial; and thirty percent thought that liars are easily recognized in most cases. The rest thought the difficulty of the credibility issue varied widely, from readily apparent to virtually impenetrable. ${ }^{116}$ Nearly all (53 out of 56) subscribed to the view that, in criminal cases, the trial process affords jurors the "essential data" needed to evaluate credibility with "an acceptably high degree of accuracy."117

I also asked the judges for a rating of five of the six standards by which jurors are asked to assess credence. ${ }^{118} \mathrm{I}$ omitted bias because I thought that doubtless its value depended entirely on the circumstances of the case. Clear winners were internal inconsistency and external contradiction. Demeanor fared somewhat less well, with few votes at either end of the value scale and most judges rating it somewhat better than middling, tending toward "one of the better indices" which deserved at least the importance that jurors usually ascribe to it. Character received eight votes as "virtually worthless" and none at the high end. For most, it was simply "one of several factors that should be taken into account." With a few more votes on the low than on the high side of the middle position of the plurality, there was some tilt of the balance toward disparagement.

Finally, I was interested to see that plausibility-which I defined as assessment of a witness's story "according to the factfinder's experience and familiarity with 'human nature' and 'the real world" -received a moderately favorable rating from the judges. No one thought it worthless and two more put it in the

115. Id. Question 1. From Kalven and Zeisel through several more modern empiricists, judicial reactions have been compared with jury verdicts. KALVEN \& ZEISEL, supra note 4, at 56; VALERIE P. HANS \& NEIL VIDMAR, JUDGING THE JURY 117-20 (1986). While I make no claim to statistical validity of even the lowest sort, I should note that the results of my poll are not altogether out of line with the more respectable work on the subject.

116. Judicial Survey II, infra Apperidix B, Question 2.

117. Id. Question 5.

118. Id. Question 4. 
"preeminent indicator" category (five) than gave it the "some value". rating (three). A substantial plurality (twenty-nine) called it one of the better indices, deserving at least the value jurors probably accord it.

I wish I could take heart in the reactions of this panel of experts. It would be comforting to believe that, despite misgivings, the confrontational mode of adjudication delivers verdicts as true as can be reasonably expected of a system based on human cognition. Yet I cannot altogether believe that judges perceive the product errors and inherent flaws of the familiar adversary mechanisin; judges, after all, may make the same errors in assessing credibility as their juries. And experience, while it may nourish confidence, provides virtually no external verification of disposition.

Judicial gullibility may also be suggested by the fact that a strong plurality of twenty-five judges expressed agreenent with the proposition that most witnesses tell the truth most of the time regardless of self-interest. ${ }^{119}$ Five additional votes were cast for the proposition that most people who lie do so only to further a just outcome as they see it. Only about half of this combined total agreed with me that most people lie under oath in direct proportion to their interest in the outcome and their belief im the persuasiveness of the lie.

I am forced to conclude that judges, well situated as they may be, are frequently drawn into the system over which they preside. Their pride depends in some measure on the faith that their efforts propel this cumbersome system toward a creditable result. In their role, I am sure I would be inclined in the same direction; it would be extremely difficult to live with skepticism concerning the important process in which one is so directly involved. Thus, to the extent the judges express confidence in jury judginent, witness veracity, and the conventional mechanisins for detecting falsehood, I must question the reliability of their judgment. And to the extent they differ from their juries and doubt the efficacy of the credence detectors, I think their opinions support my own suspicion that the validity of verdicts is largely unknowable, and the correspondence of outcome to historical fact is probably less than we would like to believe.

119. Id. Question 3. 


\section{CONCLUSION}

The central question, vital to our adjudicative model, is: How well can we expect a jury to determine credibihty through the ordinary adversary processes of live testimony and vigorous impeachment? The answer, from all I have been able to see, is: not very well, and inost probably not nearly as well as the jurors themselves and most trial judges believe. Just because the system works in the sense that juries do dehiver the unanimous verdicts deinanded of thein with a fair degree of regularity, and in the sense that trial judges more often than not would have voted as their juries did, does not mean that the system works in the sense that verdicts correspond to historical fact with an acceptably high degree of certainty. The critical correlation is not knowable, of course, but a close examination of the methods available to reach an accurate result leaves considerable doubt as to whether they are sufficiently reliable to warrant the confidence that we repose in them.

Character - an available index of propensity to fabricate testimony -is a complex and dangerous area of evidence law. The Federal Rules of Evidence, clear and simple on the surface and recently amended for further clarification, are in fact mined with ambiguities. And-as my survey illustrates-basic and vital points affecting the access of the jury to data affecting character are differently understood and differently applied from courtroom to courtroom. This confusion in the application of law may reflect the fact that we simply do not understand the role of character in predisposing a witness to perjury and cannot recognize the conduct that inplies propensity to render truthful or untruthful testimony. Masking our fundamental ignorance, we promulgate a set of rules-applicable virtually at judicial whim-that neither provides jurors with useful facts nor guarantees to shield defendants from prejudicial inferences. Simply put, the credibility factor may be a wild card that could seriously undermine our claims of faith in the adversary adjudicative system of justice.

Perhaps such success as may be fairly claimed for our mode of criminal justice-success defined in terms of the correspondence between historical fact and synthetic fact-is owed entirely to the openness, thoroughness, and good fortune of the inquisitorial police investigation that precedes it. A skilled and lucky job accuses the culprit; a misguided one names the wrong person. The trial itself may be only a roll of the dice, comparable to the ordeal 
from which it sprang, according the guilty defendant an opportunity for the intervention of irrational deliverance while threatening confirmation of the false accusation.

It is difficult for the faithful to receive this heresy with equanimity. Many of us have spent a professional lifetime defending the wisdom of juries and reporting the views of judges and litigators that, by and large and overall, juries come out right. ${ }^{120}$ We worry about the occasional undeniably erroneous verdict, but we take these as aberrational, the regrettable price of a generally benevolent jurisprudential heritage.

Yet even we devoted venirists must adınit a tickle of misgiving. It is just possible that juries generally do the right thing, because they usually convict on good police work and acquit on the inconclusive investigation. Thus, we tend to agree with the judgment of the jury insofar as it constitutes a verdict on the quality of the imvestigation. But a convincing case may be built on false testimony, and the weak case nay belie a discredited witness's tale. How good is the jury at recognizing the dubious testimony supporting the solid case or seeing the truth through the incoinplete evidence of guilt? These are the places where the jury presumably adds something to the process. In assessing the unique contribution of the jury, we should ask not how well it serves to validate the police work, but rather, whether it enhances the validity of the investigative conclusion.

If not, it may well be (as the Europeans have known for a long time) that the guilty are more accurately separated from the innocent by careful and thorough investigation than by trial. If we can bring ourselves to acknowledge the weakness of the adversary mode for these purposes, perhaps we should look with greater interest at Continental justice. ${ }^{121}$ We might ask whether, within

120. I, for one, began a recently published article with the sentence: "While most verdicts in criminal cases are probably true or nearly so, jurors occasionally err." Uviller, supra note 10 , at 1 (footnote omitted). That was my faith as well as the invariable coinment I heard from judges. I have begun to wonder whence we derive the confidence behind that assertion.

121. For a debate on the characteristics of the "inquisitorial process" of modern European criminal justice and the possibilities for import, see Abraham S. Goldstein \& Martin Marcus, The Myth of Judicial Supervision in Three "Inquisitorial" Systems: France, Italy, and Germany, 87 YALE L.J. 240 (1977), and Comment on Continental Criminal Procedure, 87 YALE L.J. 1570 (1978), on the one side; and John H. Langbein \& Lloyd L. Weinreb, Continental Criminal Procedure: "Myth" and Reality, 87 YALE LuJ. 1549 (1978), on the other side. 
our constitutional structure, we can improve the investigative phase of the process. We might explore ways to increase the investigating officers' access to facts, might consider whether abuse and excessive zeal-as well as misguided pursuits-inight be curtailed by greater supervision by judicial or quasi-judicial officers. We might ask what it would take to imbue investigative officers with the sense that duty requires vindication of the innocent as well as conviction of the guilty. In short, my mclination is to explore methods coinpatible with values of the Bill of Rights by which the shortcomings of truthseeking inherent in the adversary trial might be coinpensated by more serious investigation.

Some observers, inulling over similar problems, have proposed more grandiose solutions. Professor Richard Friedınan of Michigan, for example, advised by a cadre of eleven, recently proposed a "sweeping reform." 122 Offering a bold, original, psycho-Bayesian analysis (his description), he concludes with a politically correct but otherwise unimpressive idea that all criminal defendants should be relieved of any bad acts, ill-repute, or criminal convictions in their past, and be allowed to testify as pure lambs while sullied prosecution witnesses should take the stand at the mercy of judicial discretion. ${ }^{123}$ Even Professor Friedman's wife (he confides in a footnote) dislikes the way his inind works. ${ }^{124}$ I can see her point.

Professor Friedman, of course (as he acknowledges), is not the first to have noted the price impeachment by proof of prior conviction exacts from criminal defendants. ${ }^{125}$ But he is careful to distinguish himself from those who argue inerely that prior violent behavior says little about present perjury-indeed, he has no quarrel with the psychologists who find pervasive lying part of the criminal personality. Instead, he appears to argue seriously that impeaching a criminal defendant with a prior conviction, even for a crime involving dishonesty, is "overkill" since the defendant will already be discredited by his interest in submitting a false exculpa-

I am cognizant of the irony that, as I come to this conclusion, several European systems are moving to a more adversarial model.

122. See Richard D. Friedman, Character Impeachment Evidence: Psycho-Bayesian [1?] Analysis and a Proposed Overhaul, 38 UCLA L. REV. 637 (1991).

123. Id. at 689-90.

124. Id. at 637 n.*.

125. Id. at $640 \mathrm{nn} .6-7$. 
tory story and the jury's assumption that he is guilty of the crime charged. ${ }^{126}$ Who can quarrel with Professor Friedman's thesis that where the jury is operating on the assumption that the accused is guilty, the prosecution need not resort to an attack on credibihty through evidence of bad character? Like many who pursue the Bayesian model, however, Professor Friedman loses track of the factual predicate for the vital assumption.

I wish I could offer a sweeping solution of my own. In part, I cannot because I define the problem in different terms. Professor Friedman, like all Bayesians and other formula probabilists, ignores or assumes out of his equation the very factor I consider critical: witness credibility. In my view, no quasi-algebraic construct informs the analyst about how the jurors allocate credence; and without that information, calculations of probable truth are meaningless.

Moreover, unlike Professor Friedinan and the several others who have taken up the cause, I cannot see the issue simply as the unfairness of Rule 609 to defendants. If the threat of impeachment by proof of prior conviction unfairly chills a defendant's right to testify, it is because the potential for prejudice outweighs the probative value of the datum. As I have indicated, I fully agree that it does. But, largely because the probative value is so low, prejudice to the prosecution would preclude such evidence where offered by the defense. I also regard the information adduced under Rule 608 concerning the character of a defendant-or any witness-as of slight value on the issue of testimonial mendacity. And these observations lead me not to mislead the jury by purging only the defendant's history, but rather to the worrisome conclusion that evidence of character is but one more false hope in the discouraging mission of the law of evidence to light the way of the jury to a true assessment of credence.

The only feature of a prior criminal conviction that might boast some true probative value has never been thought by anyone to be a datuin of any significance: If the witness testified at his prior trial, and the verdict of the jury necessarily represented a rejection of that testimony, then the fact of conviction-regardless of the crime-implies conduct (i.e., perjury) that is sufficiently close to the conduct at issue that a persistent disposition might be inferred-especially if the present witness is the present defendant.

126. Id. at $660-61$. 
Short of this rather dubious reform, it is very difficult to rationalize the use of character evidence on the issue of credibility. Indeed, the Federal Rules may have stood common sense on its head, for the inference of disposition is more readily and reasonably drawn in the instance of primary criminal conduct than in the imstance of testimonial perjury.

Yet it is unmistakable in judicial attitudes-which probably reflect the views of the general public-that there is something offensive to justice in a witness presenting himself to the jury shorn of a criminal history and appealing for credence on performance alone. The artificiality of the forum is such that the law craves some means for introducing three-dinensionality for the principal players. Character is the obvious choice.

But, on sober reflection, we cannot escape the conclusion that, along with the other means for judging credence afforded to the jury, character does more to coinfort the participants than to sharpen their judgment. And the potential of such evidence to mislead jurors in their allocation of credence may be stronger than the assistance offered by this narrow slice of personality. The derivation of the rule of character impeachment, we should remember, is the disqualification of felons, a notion of moral infection we long ago abandoned. The residuum in today's rule of impeachinent bears little inore credit than its progenitor. And we could live with a ban on character inpeachment at least as comfortably as we do with the rule against character as evidence of propensity.

This conclusion, however, does not address the larger cause of disquiet. With or without impeachment-by-character, the imstruments provided to a jury for their measurement of credibility are woefully inadequate to the task. Our confidence in this keystone of the arch of justice is baseless. Reliability has never been-and can never be-tested, and our own life experiences should lead us to suspect that jurors in a courtrooin are somewhat less able to read mendacity in the testimony of a stranger than the rest of us can in ordinary circumstances-which is to say, not well at all. The extent to which the presiding judges, guided by a uniform code, can enhance the weak signal froin the witness stand is highly dubious. And their widely differing practices on a few critical calls suggest that they too are floundering for lack of trustworthy guides to credence. 
It may be time to allow ourselves to acknowledge the weakness of the adversary system in providing the means to recognize falsifiers; lacking this critical element, we may need to begin a serious exploration of truthseeking mechanisms other than our venerable dialectical confrontation. 


\author{
APPENDIX A \\ JUDICIAL SURVEY I ${ }^{127}$ \\ IMPEACHMENT BY EVIDENCE OF BAD CHARACTER
}

Please check as many lines as express your views.

1. When a witness is impeached pursuant to FRE 608 or 609 , 23 I made no distinction between a defendant in a criminal case and other witnesses before December, 1990, and I don't believe that the amendment of FRE 609(a) will alter this practice.

I

4 regularly

3 frequently

5 occasionally

distinguished between criminal defendants and other witnesses prior to December, 1990, but with the enactment of the amendment to FRE 609(a), I no longer believe such distinction to be appropriate.

35 In view of their jeopardy, I have always weighed the prejudice factor more heavily when the witness impeached is the defendant in a criminal case, and I expect I shall continue to do so notwithstanding the amendment of FRE 609(a).

8 The only distinctions between criminal defendants and other witnesses that I believe are now appropriate are: (1) that the possibihty of confusion and inefficiency resulting from impeachment by prior conviction may not be considered when the impeached witness is the defendant in a criminal case, and (2) evidence of prior convictions should be excluded in impeaching ordinary witnesses only when the prejudice factor is substantial;

20 since these distinctions are evident in the text of the annendment rule, I assume they were intentional and I shall do my best to observe them.

3 I believe these distinctions are technical (if not inadvertent) and I shall disregard them.

127. The survey responses are on file with the Duke Law Joumal. 
2. If a "character witness" is called to offer evidence in the form of an opinion per FRE 608(a),

39 I do not allow the witness to be asked the basis for his opinion since FRE 608(b) does not allow proof of specific instances of dishonest conduct by extrinsic evidence.

26 I allow the witness to be asked the basis for her opinion despite FRE 608(b) since I cannot believe the Rules intended to preclude jury consideration of the basis for an opinion offered by any witness on any subject.

3. When a party seeks to impeach a witness by eliciting a prior conviction, I

25 always

29 sometimes

14 never

take into account the nature and circumstances of the underlying criminal conduct (in addition to the elements of the crime of conviction) in determining whether it is a crime involving dishonesty under FRE 609(a)(2) [old or as amended].

4. If the crime is not a crime involving dishonesty, but was a felony where coinmitted, I

18 always

34 sometimes

14 never

consider the seriousness of the prior offense in weighing its probative value under FRE 609(a)(1) [old or as amended] because I believe the gravity of a crime necessarily/occasionally/never affects the disposition of the criminal to lie as a witness.

5. In a criminal case, if the prior crime is substantially similar in name or means of commission to the crime on trial, I

15 regularly

28 occasionally

15 rarely

6 never

exclude it on grounds that prejudice necessarily outweighs probative value;

44 if I allow it, I always give clear instructions to minimize the risk that the jury will consider the prior crime evidence of propensity. 
6. If I disallow impeachment under FRE 609, I

\section{0 regularly}

19 sometimes

41 never

allow the specific acts underlymg the conviction to be adduced under FRE 608(b) insofar as they may be probative of veracity. In this regard,

19 I believe FRE 608 is independent of FRE 609;

42 I do not think FRE 608 should be used as a back door when the front door of FRE 609 has been shut.

7. If I allow impeachment under FRE 609, I

19 regularly

26 sometimes

17 never

allow the underlying circumstances to be adduced from the impeached party by way of explanation or extenuation; and/but I

6 regularly

20 sometimes

36 never

allow the underlying circumstances to be adduced by the impeaching party also, by way of amplification of probative significance on the issue of veracity.

8. Concerning the following statement:

The whole effect of FRE 609(a) is to allow impeachment by extrinsic evidence (formerly from the public record, now-apparently-from any source) where the prior criminal conviction meets the terms set forth; this Rule has no effect whatever on impeachment by inquiry of the impeached witness concerning prior convictions.

16 I agree

18 I disagree

31 It's never come up and I have not formed an opinion.

9. Concerning the following statement:

The amendment of FRE 609(a) has had no effect whatever on the impeachment of witnesses in criminal cases-a prosecution witness in a criminal trial may still be impeached by evidence of prior conviction, either extrimsically or by inquiry on cross-examination, notwithstanding the tendency of the conviction to prejudice the 
government's case to a greater extent than it would enlighten the issue of the witness's veracity.

30 I agree

10 I disagree

28 I do not yet have enough experience with it, and have not yet formed an opinion.

10. To the extent that the amendment has made no change in prior law regarding the impeachinent of prosecution witnesses by their prior convictions,

39 I think the legislative decision was wise

4 I regret that Congress missed the opportunity to change the rule

21 I will continue to allow my judgment on the prejudicial effect of convictions that inight be adduced against a criminal defendant to be affected by the fact that convictions may be adduced against a government witness. 


\author{
APPENDIX B \\ JUDICIAL SURVEY II ${ }^{128}$ \\ JURY ASSESSMENT OF CREDIBILITY
}

\author{
verdicts \\ 1. Over the years, I have found that I agreed with my juries' \\ $3390 \%$ of the time or more \\ 20 to $90 \%$ of the time \\ 3 more often than not \\ 0 less than half the time \\ 0 I am unable to say since I rarely arrive at a personal judg- \\ ment on the ultimate issue.
}

2. In reaching (or failing to reach) a conclusion on the events underlying a criminal charge or motion (privately, in the cases tried to a jury), I find credibility

0 one of the most perplexing issues; I am frequently unsure of my disposition of the credibility question

17 one of the least perplexing issues; in most cases, it is quite apparent who is lying and who is telling the truth

39 the difficulty of issue of credibility varies widely; in some cases, it is easily resolved, in others it is all but impenetrable.

3. It is only an informed hunch, but after hearing a variety of witnesses testify in various circumstances, it is my belief that:

25 most people tell the truth under oath most of the time, regardless of self interest

5 most people who lie do so only in furtherance of what they deem a just outcome

14 most people lie under oath in direct proportion to the strength of their interest in the outcome, modified only by the constraints. of inconsistent evidence and their belief in the persuasiveness of the falsehood

11 lying is largely a matter of moral temperament; those who are prone to lie require only the slightest incentive to disregard the truth.

128. The survey responses are on file with the Duke Law Joumal. 
4. Below are listed five factors commonly named as the factfinders' best methods for assessing veracity. Assuming that jurors consider one or more (as may be appropriate in a given case), please indicate by number your own personal rating of the rehability of each factor according to the following scale:

$1=$ as a general matter, virtually worthless; the factfinder is as likely to be misled as well guided by reliance on this factor

2 = may have some value in a significant number of cases, but it generally not as reliable as jurors consider it to be and should be used with great care

$3=$ one of several factors that should be taken into account

$4=$ one of the better indices of credibility; jurors probably consider it important and it deserves at least the value they ascribe to it

$5=$ clearly, the preeminent indicator and perhaps the only one that deserves serious consideration by a jury; though considered, it is probably not rated as highly as it should be

The factors:

consideration of the character of the witness as disclosed by evidence tending to show traits of honesty or dishonesty from which testimonial truthfulness or the lack of it may be reasonably inferred
(1) 8
(2) 12
(3) 22
(4) 10
(5) 0

the demeanor of the witness on the stand, including vocal and postural cues, facial expressions, and the inflections and verbal forms of response
(1) 1
(2) 12
(3) 19
(4) 20
(5) 2

evidence of the omissions, self-contradictions, \& internal inconsistencies in the witness's account
(1) 1
(2) 1
(3) 16
(4) 23
(5) 11 
comparison of the substance of the story with other evidence (testimonial or physical) on the same fact
(1) 2
(2) 2
(3) 15
(4) 24
(5) 11

consideration of the plausibility of the witness's story assessed according to the factfinder's experience and familiarity with "human nature" and "the real world"
(1) 0
(2) 3
(3) 17
(4) 29
(5) 5

5. Which of the following statennents best expresses your view regarding the jury's ascription of credence in criminal cases:

53 Though the setting and procedure are "artificial," the trial does provide jurors with the essential data to make a judgment on credibility with an acceptably high degree of accuracy.

3 Too often jurors are mislead by extraneous considerations such as: the personality of counsel; irrelevant personal attributes of witnesses; race, class, gender, or other identification with the defendant or victim; "political" hostility to the government or "the law."

0 We deceive ourselves into the belief that jurors are capable of accurate credence calls that the rest of us would hesitate to make on the same data. 